Geological
Circular

\title{
GEOTHERMAL RESOURCES FRIO FORMATION, SOUTH TEXAS
}

\author{
BY \\ D. G. BEBOUT \\ M. H. DORFMAN \\ O. K. AGAGU \\ RESEARCH ASSISTANTS \\ G. E. GRANATA \\ G. B. SANDERS, JR.
}

BUREAU OF ECONOMIC GEOLOGY

THE UNIVERSITY OF TEXAS AT AUSTIN

W. L. FISHER, DIRECTOR

1975

Second Printing, July 1976 


\section{DISCLAIMER}

This report was prepared as an account of work sponsored by an agency of the United States Government. Neither the United States Government nor any agency Thereof, nor any of their employees, makes any warranty, express or implied, or assumes any legal liability or responsibility for the accuracy, completeness, or usefulness of any information, apparatus, product, or process disclosed, or represents that its use would not infringe privately owned rights. Reference herein to any specific commercial product, process, or service by trade name, trademark, manufacturer, or otherwise does not necessarily constitute or imply its endorsement, recommendation, or favoring by the United States Government or any agency thereof. The views and opinions of authors expressed herein do not necessarily state or reflect those of the United States Government or any agency thereof. 


\section{DISCLAIMER}

Portions of this document may be illegible in electronic image products. Images are produced from the best available original document. 
A preliminary study of the Frio sand distribution and formation temperatures and pressures was undertaken in order to define prospective areas in which a more detailed reservoir analysis is necessary prior to the selection of a site for a geothermal well.

As the result of prospective oil wells that penetrated the Tertiary sediments, a geopressured zone containing fluids with high temperatures is known to occur along the Texas Gulf Coast. Few oil or gas wells produce from this area, and the regional sand distribution within these zones is not well known. Limited data, however, indicate that the pore spaces within the sands in the geopressured zone are filled with water which has high temperatures and relatively low dissolved-solids content, and which is saturated with methane. These waters are believed to be an important source of the rmal energy and methane gas. For more information concerning the origin of the geopressured zone, see Dorfman and Kehle (1974) and Jones (1970).

The first step in appraising the Gulf Coast geothermal resources entails a detailed geologic study of the main sand trends; the Frio and Wilcox Formations appear to be the best prospects (fig. 1). This report will deal largely with the Frio. The Wilcox
Formation has been studied by Fisher and Mc Gowen (1967). Other parts of the Tertiary which have been studied in detail are the Queen City Formation (Claiborne), which was reported on by Guevara and Garcia (1972), and the Jackson, reported on by Fisher and others (1970).

The United States Atomic Energy Commission, through the Lawrence Livermore Laboratory, and the Center for Energy Studies, The University of Texas at Austin, supported this preliminary study of the geothermal resource of the Frio sands in South Texas. The South Texas area (from just north of Corpus Christi and south to the Rio Grande, fig. 2) was selected because the geopressured zone is known to occur here at shallow depths (Jones, 1970), and because of the abundance of oil well records for the area. The study includes a sandfacies analysis and an integration of the facies data with existing information relative to temperatures and pressures. 


\begin{tabular}{|c|c|c|}
\hline AGE & SERIES & GROUP/FORMATION \\
\hline \multirow{2}{*}{ Quaternary } & Recent & Undifferentiated \\
\hline & Pleistocene & Houston \\
\hline \multirow{7}{*}{ Tertiary } & Pliocene & Goliad \\
\hline & \multirow{2}{*}{ Miocene } & Fleming \\
\hline & & Anahuac \\
\hline & Oligocene & 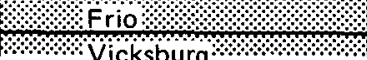 \\
\hline & \multirow{3}{*}{ Eocene } & $\because \because$ Jackson $\because \cdots$ \\
\hline & & Claiparne \\
\hline & & $\frac{\text { Midway }}{\text { Midcoxä }}$ \\
\hline
\end{tabular}

Fig. 1. Tertiary formations--Gulf Coast of Texas. Of prime interest in this report is the Frio and upper part of the Vicksburg (shown in the darker pattern); other formations already studied and summarized in Bureau reports are shown with the lighter pattern.

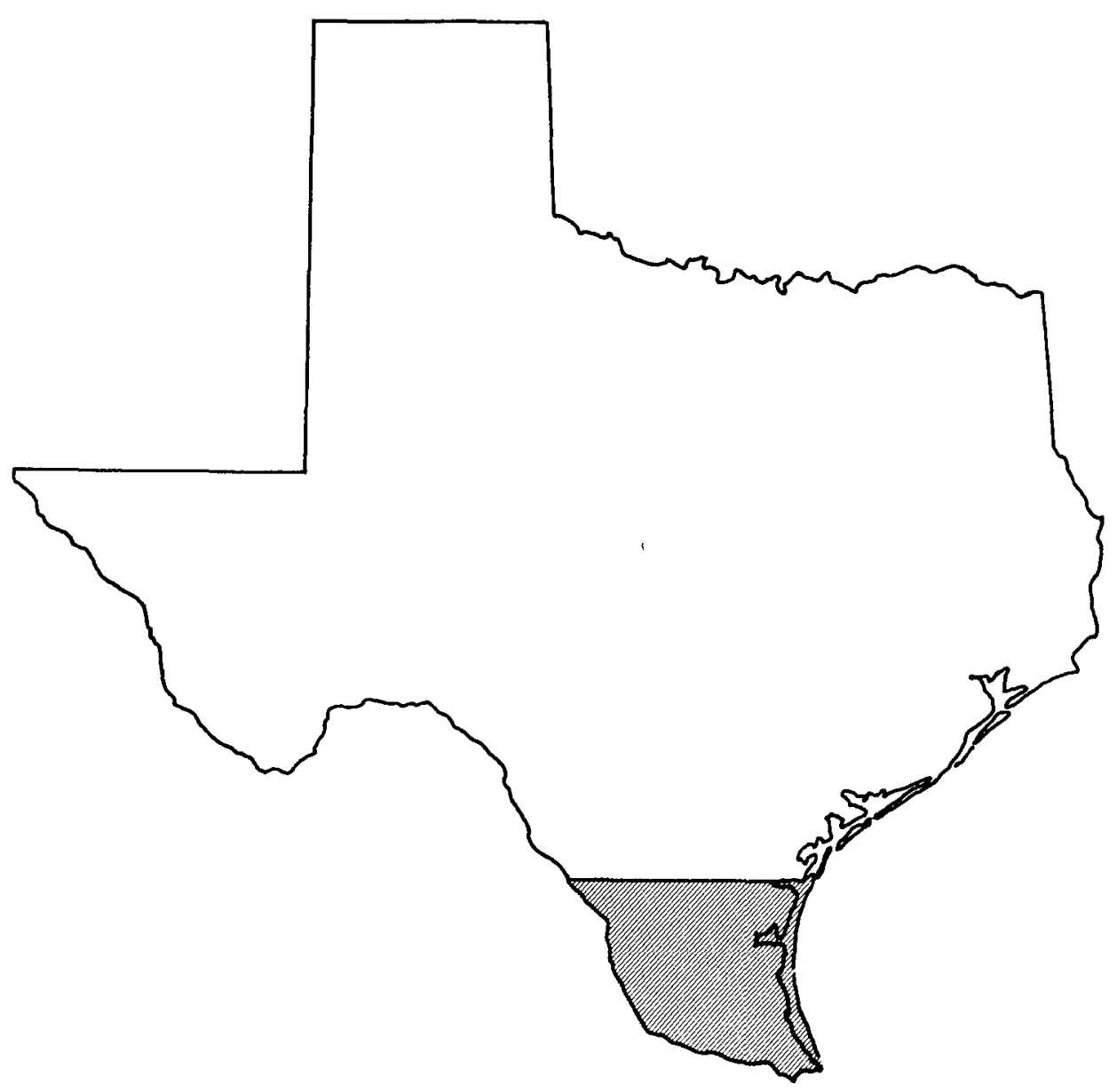

Fig. 2. Area of study. 
DEPOSITIONAL PATTERNS--GULF COAST TERTIARY

The Tertiary of the Gulf Coast comprises a large number of basinward-thickening sand-shale wedges which, because of their similarities, are very difficult to separate stratigraphically from one another.

The Tertiary of the Gulf Coast is made up of a number of sand-shale packages which dip steeply into the Gulf of Mexico (fig. 3); each of the se packages also thickens considerably in the same direction forming a wedge shaped body (fig. 4). The wedges are dominantly shale with scattered, discontinuous sand bodies at the thin landward end; thick sand with thin shales in the central portion; and thick shale with thin, relatively continuous sands at the downdip portion of the wedge. In general, each younge $r$ wedge is displaced gulfward from the preceding wedge.

This Tertiary section is too thick and areally extensive to study as a single unit; consequently, it has been necessary to subdivide it into genetic units. This subdivision is difficult on the basis of lithology alone because of the repetitiveness of sand-shale occurrence and the lack of recognizable physical breaks. Thus, organizations exploring for oil and gas in this section found it necessary to use evolutionary change within foraminiferal groups, present in the marginal marine portions of the wedges, to subdivide grossly the Tertiary section. Major foraminiferal zones significant to this study are shown on Figure 5. The marine portion of each wedge containing foraminiferal markers is displaced progres sively gulfward from the preceding wedge; this phenomenon is shown on the foraminifer zone updip limit map (fig. 6a) on which each older zone lies farther inland than the next younger, thus substantiating the pattern shown on Figure 4. 


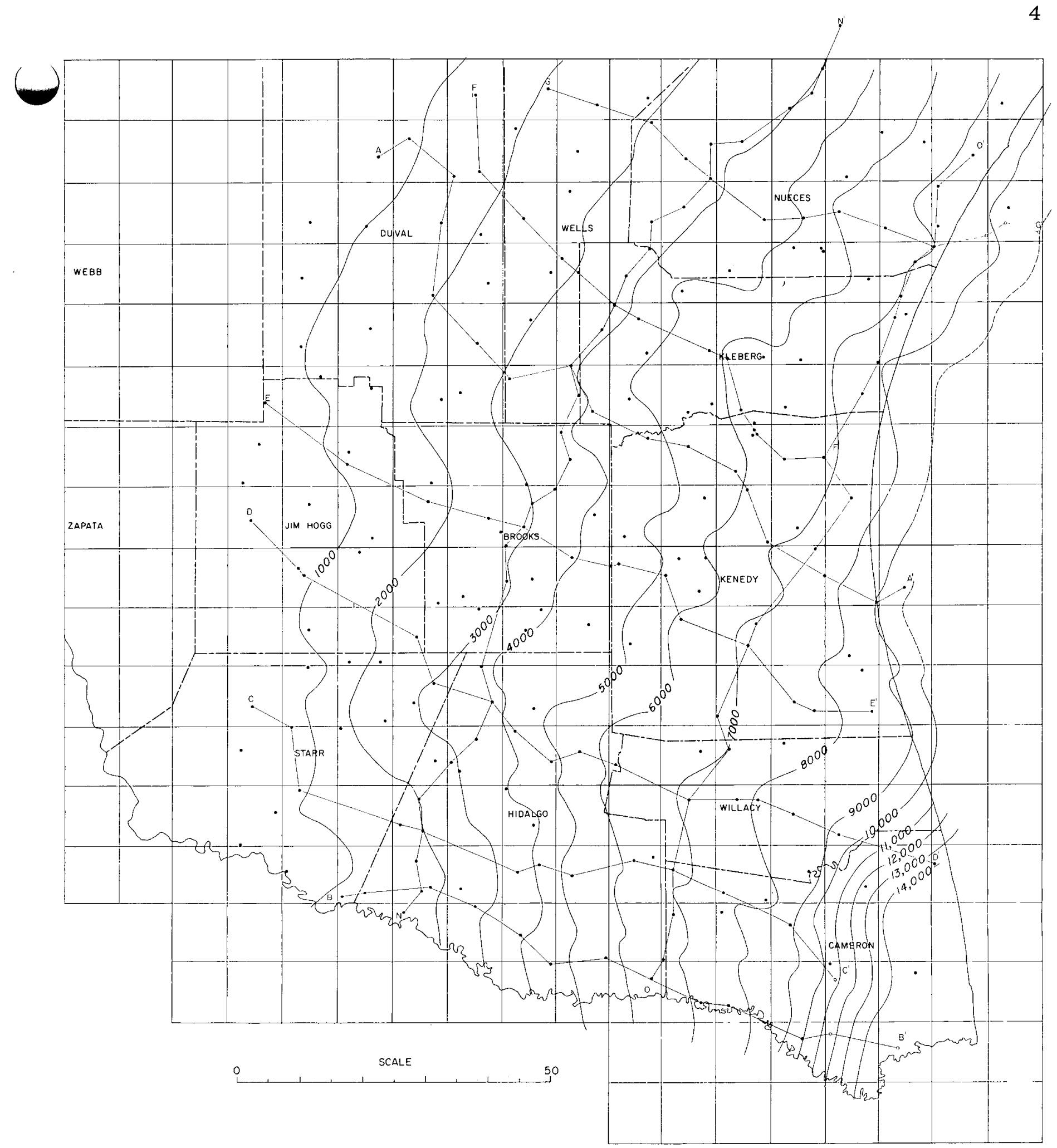

Fig. 3. Structure on top of the Frio Formation. 


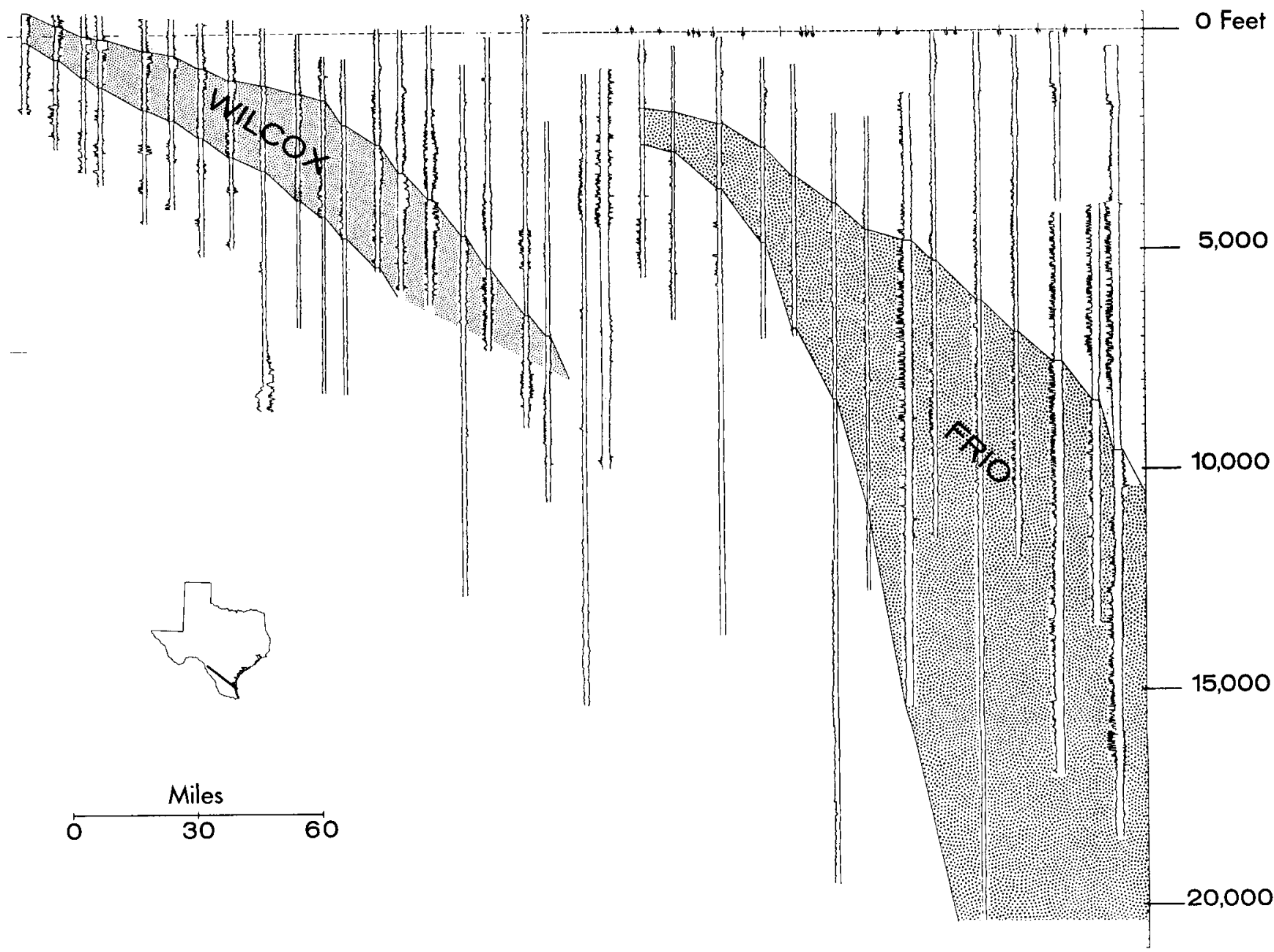

Fig. 4. Regional cross section on a sea-level datum showing the pattern of sand-shale packages offlapping toward the coast.

\begin{tabular}{|c|l|l|}
\hline SERIES & GROUP/FORMATION & \\
\hline Miocene & Anahuac & $\begin{array}{l}\text { Discorbis nomada } \\
\text { Heterostegina texana* } \\
\text { Marginulina vaginata* }\end{array}$ \\
\hline Oligocene & Frio & $\begin{array}{l}\text { Cibicides hazzardi } \\
\text { Nonion struma } \\
\text { Nodosaria blanpiedi* } \\
\text { Textularia mississippiensis } \\
\text { Anomalia bilateralis }\end{array}$ \\
\cline { 2 - 3 } & Vicksburg & Textularia warreni* \\
\hline
\end{tabular}

Fig. 5. Foraminifer zonation, Texas Gulf Coast Miocene and Oligocene. 

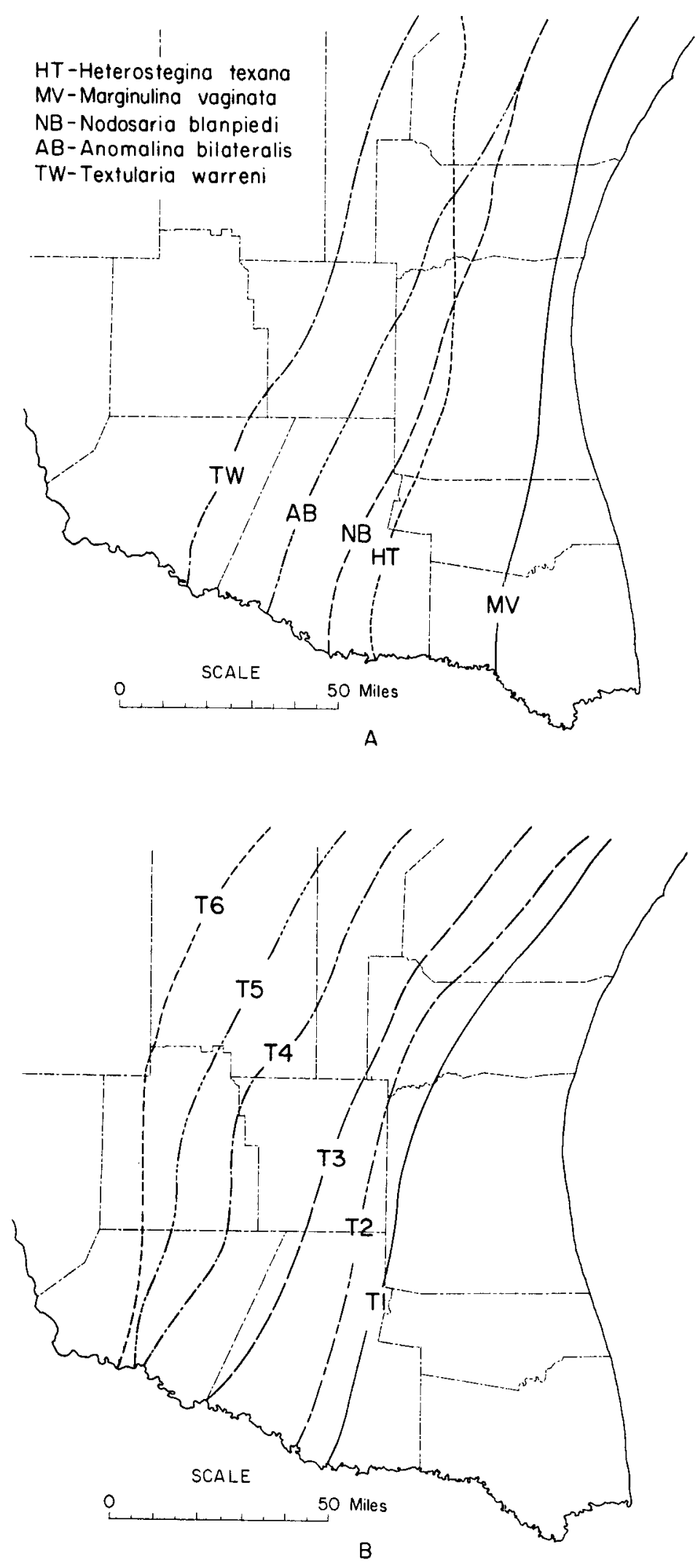

Fig. 6. (A) Updip limits of foraminifer markers (after Holcomb, 1964) and (B) Updip limits of "T" markers. 
Abundant down-to-the-basin growth faults a re well known as a method of thickening sand-shale sections in the Tertiary of the Gulf Basin.

Much of the thickening, which is manifest regionally as thick sandshale wedges, is believed to have been caused by contemporaneous growth faults (fig. 7). Because the faults are active as sedimentation is taking place, older strata a re displaced more than younger strata and considerable thickening of the sedimentary units involved occurs on the gulfward or down side of the fault. A regional or structural cross section (fig. 8) shows the cumulative effect of crossing several growth faults; the uniform thickening shown on the regional facies sections actually represents an averaging of the effects of these faults.

Because of the complexity of the faulting in South Texas (figs. 7, 8, 9, and 10), it is impossible to portray these faults on the regional sections. The displacement is quite variable along most of the faults and for many is only a few hundred feet. Because of this complexity and small displacement, it was considered preferable to study the sand distribution region- ally, at first without regard to the faults, though realizing that growth faulting is common and is the normal mechanism for providing space to thicken the section rapidly downdip. The faults are not believed to have affected the depositional patterns appreciably except for significantly more thickening.

The location of growth faults, confirmed by seismic sections of regional and local nature, will be of critical importance late $r$ when attention is focused on the selection of local prospective areas. As a result of growth faulting, porous sand reservoirs once in contact with timeequivalent extensive sand units updip may be displaced downward on the coast side of the fault to then be in contact, across the fault, with impermeable shale (fig. 10). Thus, extensive oil and gas reservoirs and potential geothermal reservoirs developed as a result of sedimentary processes along with contemporaneous structure. 
Fig. 7. Depositional thickening as a result of contemporaneous growth faulting (from Bruce, 1973).
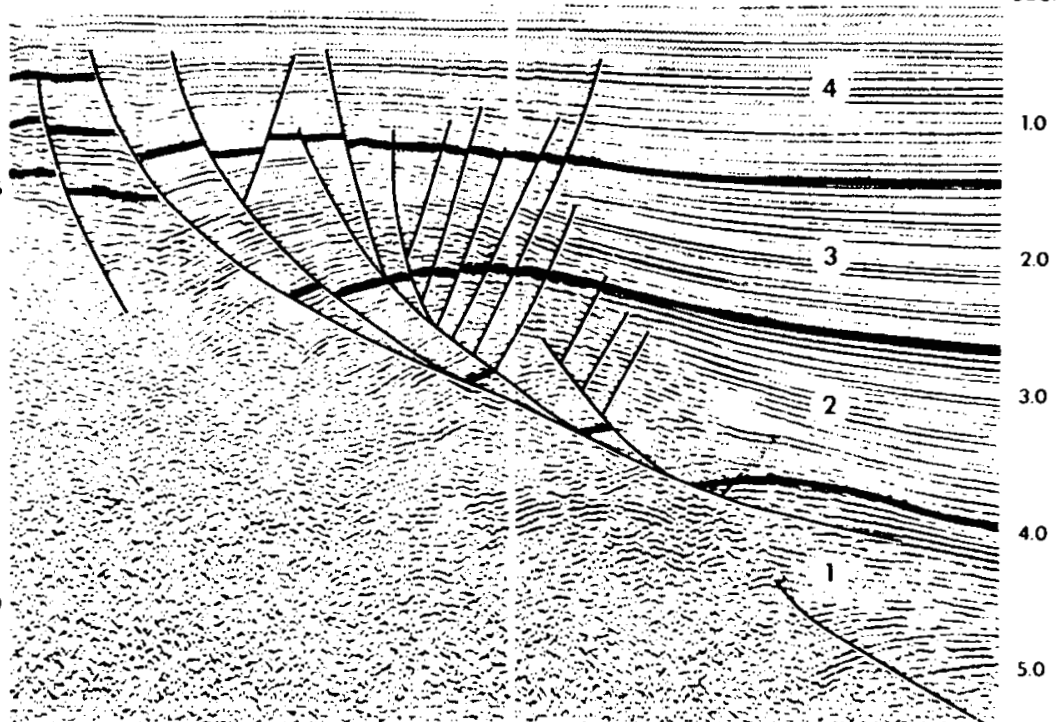

MILES

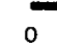

0

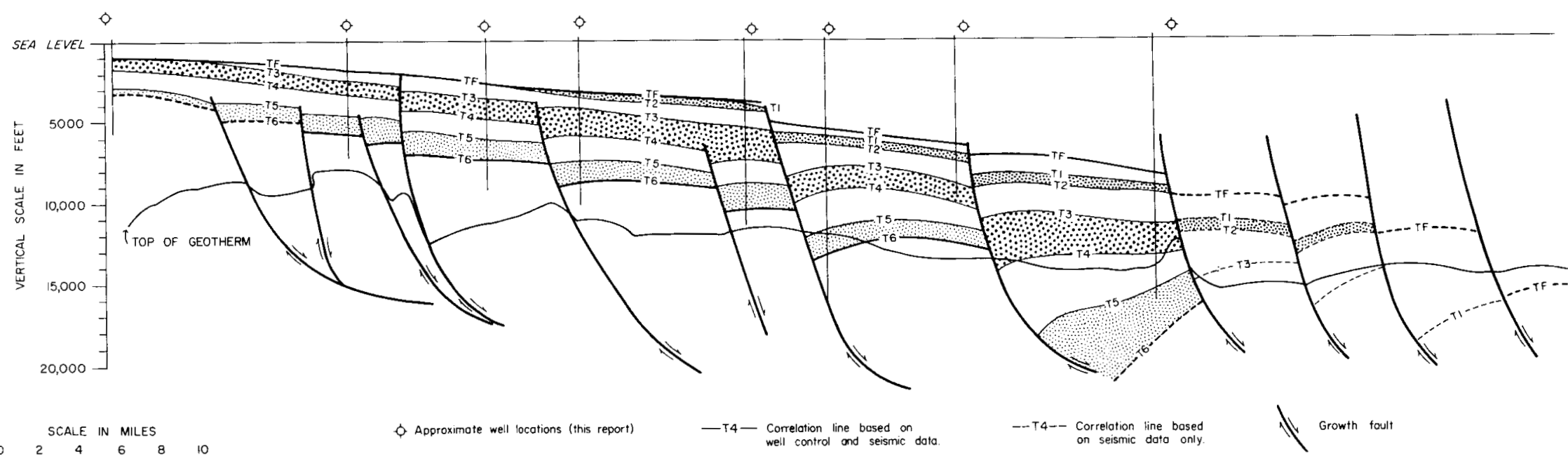

Fig. 8. Diagrammatic regional cross section adapted from a seismic section and from electrical log and paleontological control. This section parallels the $\mathrm{B}-\mathrm{B}$ ' section near the Rio Grande; the "T" markers from the $\mathrm{B}-\mathrm{B}^{\prime}$ section have been projected into this section to show the relationship of the depositional patterns (interpreted from electrical logs) to the growth faults (interpreted from the seismic sections). 


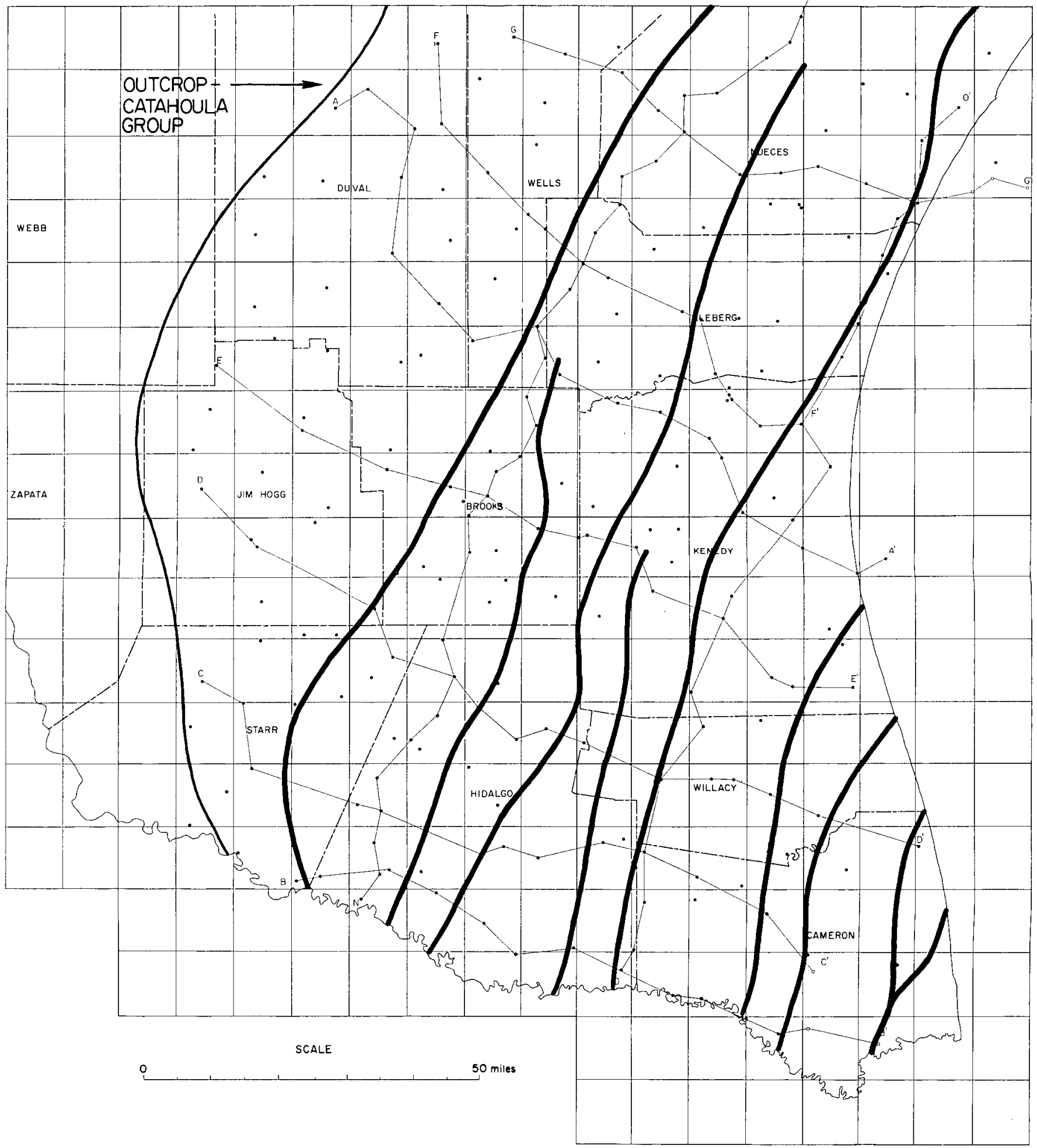

Fig. 9. Generalized location of growth faults in South Texas. 

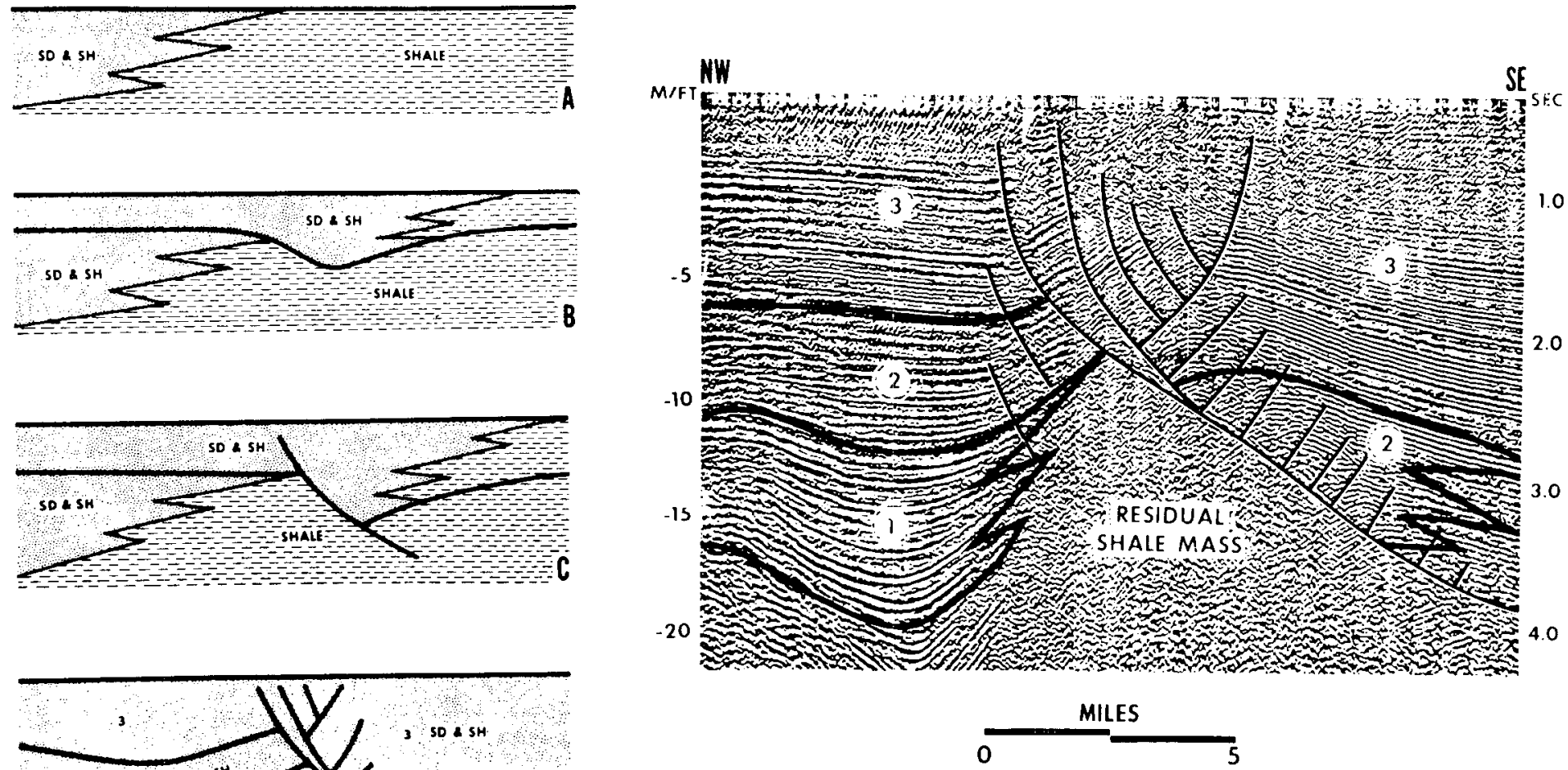

Fig. 10. Seismic section showing the location of a growth fault and the displacement of sand bodies and development of a shale ridge resulting from the faulting. The diagrams A-D illustrate the sequential development of the structure (from Bruce, 1973). 
In order to determine regional sand distribution, it is necessary to obtain optimum welllog control, construct cross sections, and develop a correlation framework.

Reliable resource assessment is based on a thorough understanding of the sand distribution and geometry. In sand-shale sections this type of regional information is commonly obtained through the construction of a grid of dip and strike electrical log cross sections. On these cross sections, detailed correlations lead to the subdivision of the section into smaller, more meaningful, and easily handled units.

For the Frio study, 232 electrical logs were obtained from wells spaced approximately 5-10 miles apart throughout the South Texas area (fig. 11). Only those wells which penetrated the entire Frio were selected except in the downdip areas along the coast where no wells penetrated the entire Frio section. The top and base of the section were picked with the aid of micropaleontology-Heterostegina and Marginulina are near the top of the Frio and Textularia warreni is near the base. Where these markers are lacking structure and major shale breaks were used.

A total of seven dip sections and two strike sections were constructed of the Frio section, using the top of the formation as a datum. The se sections illustrate the Frio as a wedge of sediment less than 1,000 feet thick on the updip end of the section and more than 10,000 feet thick on the downdip end (see map on cover). 


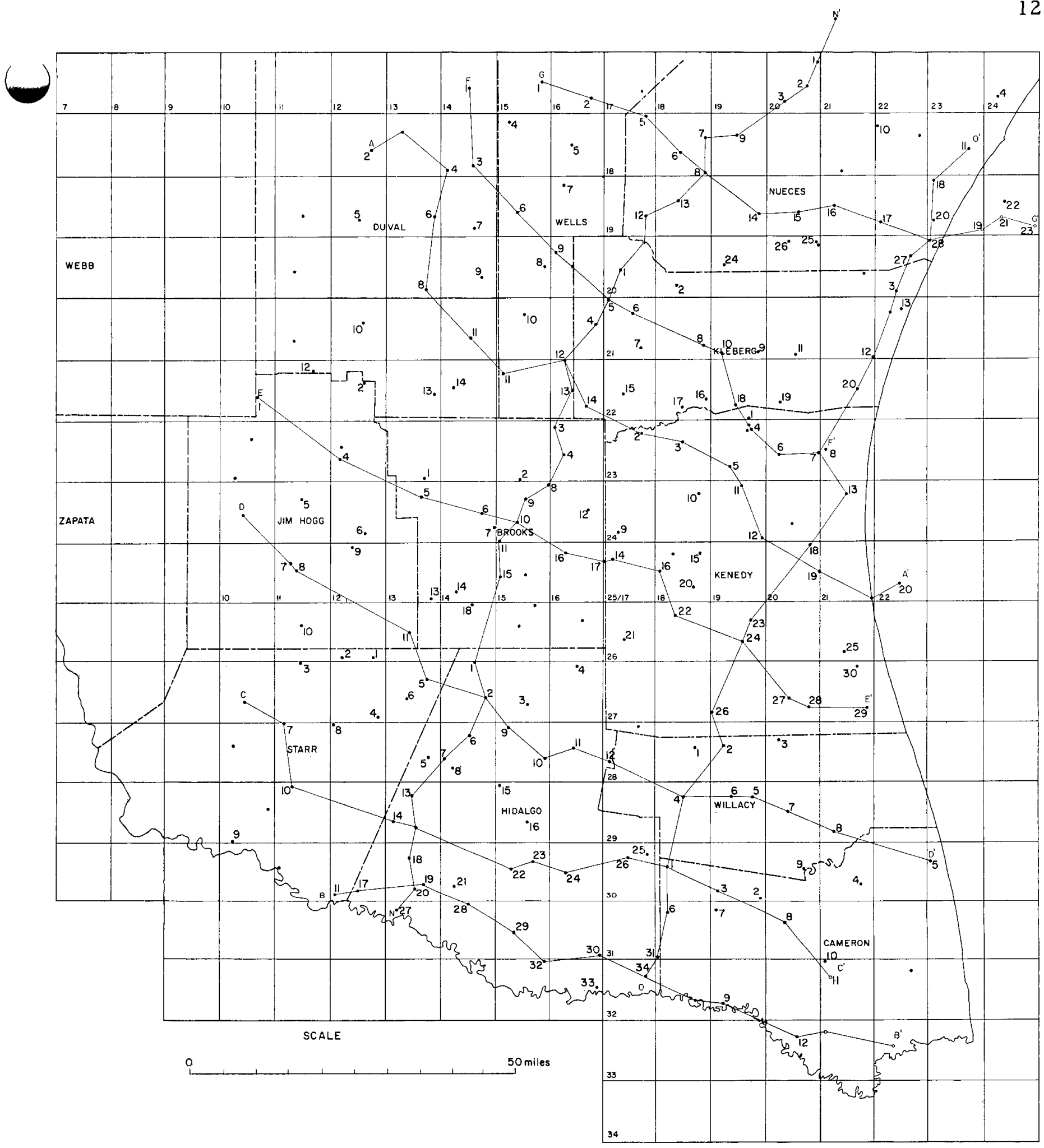

Fig. 11. Well-log control and cross sections constructed for this Frio study. 


\section{Brooks County}

1. City Products Corp.

2. Shell Oil Co.

3. General Crude Oil Co.

4. Gunther, Warren \& Gulf Oil Corp.

5. Russell McGuire

6. NOR-MAC-Burns

7. Humble Oil \& Rfg. Co. 8. Carrl Oil, General Crude, Pan Am.

9. Forest Oil Co.

10. Forest Oil Co.

11. Humble Oil \& Rfg. Co.

12. Humble Oil \& Rfg. Co.

13. Humble Oil \& Rfg. Co.

14. Humble Oil \& Rfg. Co.

15. Humble Oil \& Rfg. Co. 16. Humble Oil \& Rfg. Co.

17. Humble Oil \& Rfg. Co.

18. Standard Oil of Texas
G. S. Saunders et a1 1

J. L. Cage \#C-1

R. G. Garza \#1

Miller et al. \#1

Saunders \#1

J. L. Cage \#1

C. F. Hooper \#7

R. G. Cage et al. \#1

Cage Ranch \#1

Ed Rachal Foundation \# 1

C. F. Hopper $\# 5$

D. J. Sullivan "B" \#28

Mestena Oil \& Gas Co. \# G-5

Mestena Oil \& Gás Co. \#G-3

B. A. Skipper, Jr. \#11

R. J. Kleberg, Jr.,

Trustee, Los Muertos Pasture \#7

J. Kleberg, Jr., Trustee, Sacahuista Pasture \#2 Braulia de Garcia \#1-14

\section{Cameron County}
1. Texaco, Inc. (proprietary)
2. Amerada Petr. Corp.
3. Gulf Oil Corp.
4. Shell Oil Co.
5. Magnolia Petr. Co.
6. Hydrocarbon Prod. Co.
7. Harkins \& Co. \& R. Mosbacher
8. Aluminum $\mathrm{Co}$. of America
9. Brazos Oil
10. Holmes Drlg. Co.
11. Dow Chemical
12. Humble Oil \& Rfg. Co.

C. A. Johnson \#1

W. O. Huff \#1

J. H. McDanie1 \# 1

Continental Fee \#1

G. Ke rlin \#1

J. R. Bevers et al. \#I

L. Rohman \#1

Old Colony Trust Est. \#1

State Tract 215 \#1

T. Sweeney et al. \#1

Conoco Mineral Fee \#1

Cameron County Water

Control \& Improvement District 6 \#1

Hidalgo County

1. Humble Oil \& Rfg. Co.

2. Shell Oil Co.

3. Shell Oil Co. et al.

4. Humble Oil \& Rfg. Co.

5. Pontiac Rfg.

6. Shell Oil Co.

7. Shell Oil Co.

8. Taylor Oil \& Gas Co.

9. Shell Oil Co.

10. Magnolia Petr. Co.

11. Magnolia Petr. Co.

12. N. E. Hanson

13. P. H. Welder

14. Coastal State

15. Austral Oil Co., Inc.

16. Humble Oil \& Rfg. Co.

17. Phillips Oil

18. Sinclair Prairie Oil Co.

19. Humble Oil \& Rfg. Co.

20. Coastal States

21. Houston Oil Co. of Texas

22. Mokeen Oil Co.

23. Amerada Petr. Corp.

24. Union Prod. Co.

25. Continental Oil Co.

26. Standard Oil Co. of Texas

27. Houston Oil Co.

28. Conoco

29. Tenneco Oil

30. La Gloria Corp.

31. Shell Oil Co.

32. Sinclair Oil

33. LaGloria Corp.

34. Bettis \& Shepard
Mc Gill Bros, \#416

A. A. McAllen \#9

Goldston Est. \#1

Santa Fe - Mula \#7

Arrowhead Ranch \#1

A. A. McAllen et al. \#1

G. Coates-Newmont Oil Co. \#1

K. J. Alexander \#1

A. W. Beaurline \# 1

G. Doughty \#1

R. Garcia \#1

S. Dobbins \#1

W. J. Davis \#1

G. H. Coate s et a1. \#1

R. Vela et al. \#1

B. Hanks \#1

Flores \#1

S. Geininger $\# 1$

Texan Dev. Co. \#1

T. E. Murchison \#1

Hidalgo-Willacy \#A-1

J. T. Atwoed \#1

T. \& N. O. RR. Co. \#1

Wysong Unit \#2

E. E. Johnson \#1

Rio Farms Inc. \#1

Hidalgo-Willacy Oil Co.

M. L. Talbot \#1

McAllen Field Wide Unit \#36

South Weslaco Gas Unit \#

H. W. Drawe \# 1

Houston Unit \#2

South Weslaco Gas Unit \#11

Schwartz \#1

\section{Jim Hogg County}

\section{British American Oil Prod. Co.}

2. Humble Oil \& Rfg. Co.

3. Cox Hamon

4. W. Young

5. P. L. Davidson

6. G. C. Ayres

7. The Texas Co.

8. Burns Trust $\# 2$

9. E. R. Thoma

10. Sun Oil Co.

11. Humble Oil \& Rfg. Co.
Adams \#1

Mestena Oil \& Gas Co. \#C-2 Armstrong \#1 Mestina \#3

Well Bros. \#1

Mestena Oil \& Gas Co. \#4

A. K. East \#6

East \#1

Holbein \#1

A. C. Jones \#63

A. M. Bass \#30

\section{Jim Wells County}

\section{Duval County}

1. C. C. Winn

2. Shell Oil Co.

3. Humble Oil \& Rfg. Co.

4. Taylor Rfg. Co.

5. Pyramid Drlg. Co.

6. The Texas Co.

7. Humble Oil \& Rfg. Co.

8. Hiawatha Oil \& Gas Co.

9. Quintana Petr. Corp.

10. Hillcrest Oil Co.

11. Hunt Oil Co.

12. Arco Oil Corp.

13. Texaco, Inc.

14. Continental Oil Co.
Salinas Est. \#2

Stegall \#A-1

E. Garcia \#1

Parr \#T-2

J. M. Luby Est. \#1

Gravis \#1-A

W. W. Garcia \#1

Parr \#D-1

Frank \& Clyde Allen \#1

K. Shaffer $\# 1$

Dechampa \#1

Laura McBryde \#1

Canales \#1

Glasscock et al. \#1
1. Carrl Oil et al.

2. O. Maclain

3. Texas Southern Oil \& Gas Co.

4. Gulf Coast Minerals, Inc.

5. W. E. Rowe

6. SunrayMid-Continental Oil Co.

7. Appell Drlg. Co.

8. Carrl Oil \& Shore Expl. Co.

9. Sid Katz Expl.

10. H. R. Smith

11. G. E. Chapman

12. Sun Oil $\mathrm{Co}$

13. Sun Oil Co.
Shaeffer Ranch $\# V-1$

Rehmet \#4-A

E. Monse \#2

Robles Heirs \#1

W. Meyer \#2 C. Muil \#1

H. H. Chiles \#1

A. C. Skinner \#2

J. E. Morgan \#1 C. Driscoll Est. \#1 Howell et al. Unit \#1 Canales \#117

A. T. Canales \#43 
1. Humble Oil \& Rfg. Co. 2. Gulf Oil Corp.

3. Humble Oil \& Rfg. Co. 4. Humble Oil \& Rfg. Co. 5. Humble Oil \& Rfg. Co.

6. Humble Oil \& Rfg. Co.

7. Pan Am.

8. LaGloria Corp.

9. Humble Oil \& Rfg. Co.

10. Humble Oil \& Rfg. Co.

11. Humble Oil \& Rfg. Co. 12. Humble Oil \& Rfg. Co.

13. Humble Oil \& Rfg. Co.

14. Humble Oil \& Rfg. Co.

15. Humble Oil \& Rfg. Co. 16. Humble Oil \& Rfg. Co. 17. Humble Oil \& Rfg. Co. 18. Humble Oil \& Rfg. Co. 19. Mobil Oil Corp.

20. Mobil Oil Corp.

21. Humble Oil \& Rfg. Co.

22. Humble Oil \& Rfg. Co. 23. Humble Oil \& Rfg. Co. 24. Humble Oil \& Rfg. Co. 25. Humble Oil \& Rfg. Co. 26. Texaco, Inc.

27. Humble Oil \& Rfg. Co. 28. Humble Oil \& Rfg. Co.

29. Gulf Oil Corp.

30. Continental Oil Co.

31. Humble Oil \& Rfg. Co.
S. K. East \#B-18

McGill Est. \#2

H. F. McGill \# 1

S. K. East \#B-15

J. G. Kenedy, Jr. \#"J"l-2

J. G. Kenedy, Jr. $\# \mathrm{G}-1$

Kenedy \#1

Kenedy Ranch \#B-1

R. J. Kleberg, Jr., Trustee, Patricio Pasture \#10

J. G. Kenedy, Jr. $\# \mathrm{C}-2$

Kenedy \#J-4

S. K. East \#D-1

State Tract $249 \# 1$

R. J. Kleberg,

Sacahuista Pasture\#2

S. K. East \#41

S. K. East \#17

C. M. Armstrong $\# 20$

S. K. East $\# \mathrm{C}-1$

State Tract $309 \# 1$

Texas Gulf 59202

State Tract $961 \mathrm{~L}$

Santa Fe Ranch Julian Pasture \#1

C. M. Armstrong \#22

S. K. East ' $G$ ' $\# 1$

King Ranch-Saltillo \#2

State Tract 384 \#1

Yturria $\mathrm{L}$ and $\mathrm{L}$

A NCT $-2 \# 1$

King Ranch \#2

King Ranch -

Tio Moya \#1

State Tract 427 \#1

State Tract $393 \# 1$

R. J. Kleberg, Jr., Fruste1 Stillman \#7

\section{Kleberg County}

1. Humble Oil \& Rfg. Co.

2. Golden Trend Oil \& Gas Corp.

3. Pure Oil Co.

4. Humble Oil \& Rfg. Co.

5. Humble Oil \& Rfg. Co.

6. Humble Oil \& Rfg. Co.

7. Meeker \& Hass Bros.

8. Lone Star Oil Co.

9. Humble Oil \& Rfg. Co.

10. Mokeen Oil Co.

11. Humble Oil \& Rfg. Co.

12. Humble Oil \& Rfg. Co.

13. Kelly Bell

14. Humble Oil \& Rfg. Co.

15. Humble Oil \& Rfg. Co.

16. Cities Service Petr.

17. Mokeen Oil Co. et al. 8. Sun Oil Co.

19. Humble Oil \& Rfg. Co. 20. Shell Oil Co.
King Ranch - Stratton \# T-1

Marshal1-Michele \#1

State Tract 168 \# -1

King Ranch Seeligson \#E-45

King Ranch - Borregos \#262

King Ranch -

Borregos \#ME-5

O'Conner $\# 1$

Mull \#1

King Ranch - Visnaga \#8

H. A. M. \#A-1

King Ranch - Alazan \#3

State Tract $197 \# 1$

State Tract $184 \# 1$

King Ranch -

Lagura Larga \#10

King Ranch - Canelo \#17

R. B. Poteet \#1

Yeargen \#1

Laguna Olmos

Gas Unit $372 \# 1$

Baffin Bay State Tract 57 \#1

State Tract $206 \# 1$
1. Getty Oil Co.

2. Spartan Drlg. Co.

3. Southern Minerals Corp.

4. Getty Oil Co.

5. Kirkpatrick Oil \& Gas Co. \& Natol Petr.

6. Gillring Oil

7. Southern Minerals Corp.

8. Glasscock Bros. \& Puenticitas Oil Co.

9. Richardson Petr.

10. Forest Oil Corp. \& Mobil Oil Co.

11. Shell Oil Co.

12. Champlin Oil \& Rfg. Co.

13. Puenticitas Oil Co.

14. The Atlantic Rfg. Co.

15. Newman Bros.

16. Coastal States

17. J. P. Driscoll et al.

18. Atlantic Richfield Co. \& Tidewater Co.

19. Cities Service

20. Humble Oil \& Rfg. Co.

21. Gulf Oil Co. Humble Oil \& Rfg. Co.

22. Humble Oil \& Rfg. Co.

23. Union Oil of Calif.

24. G. N. Graham

25. The Chicago Corp

26. A. O. Morgan \& Southern Minerals Corp.

7. Humble Oil \& Rfg. Co.

28. Cherryville Corp.
Wilkerson \#1

E. H. Granberry \#1

M. H. Griffith \# 1

State Tract $275 \# 1$

A. P. Regmund \#1

Winfield \#8

B. Sterns \#1

La Rochelle \#1

F. Nemec \#1

State $\mathrm{T}$ ract $786 \# 7$

State Tract 346 \#1

B. Woffa rd \#C-2

Simmons \& Perry "B" \#60

J. S. Womack

W. W. Walton \#1

P. Kraft \#1

F. D. Smith et al. \#1

St. 45-47 Unit, Tr. \#470, \#3

State Tract $773 \mathrm{~L} \# 1$

Laguna Madre

State Tract 52 \#1

State Tract 772 \# B-1

Sta te Tract 772 \#1

State Tract $775-\mathrm{L} \# 1$

Al. Dorsogna \#1

Chapman Ranch \#3

Chapman Heirs \#43-1

State Tract $173 \# 1$

B. Dunn et al. \#1

\section{Starr County}

$\begin{array}{ll}\text { 1. Richardson Petr. } & \text { E. Yzaguirre\#B-1 } \\ \text { Enterprise } & \text { Margo Est. \#A-1 } \\ \text { 2. Oil Operations, Inc. } & \text { A. C. Jones \#55 } \\ \text { 3. Sun Oil Co. } & \text { J. F. Hall-State\#1-A } \\ \text { 4. Sun Oil Co. } & \text { D. Olivarez\#1 } \\ \text { 5. Humble Oil \& Rfg. Co. } & \text { F. B. Guerra \#5 } \\ \text { 6. Magnolia Petr. Co. } & \text { O. B. Simpson } \\ \text { 7. Sun Oil Co. } & \text { State\#1 } \\ \text { 8. Sun Oil Co. Coates } & \text { State\#A-4 } \\ \text { 9. Owen \& Moss } & \text { W. S. Parks \#4 } \\ \text { 10. Lockhart Oil Co. } & \text { J. D. Brock\#2 } \\ \text { of Texas } & \text { Reilly \#A-1 }\end{array}$

Willacy County

1. Humble Oil \& Rfg. Co.

2. Texaco Inc.

3. Humble Oil \& Rfg. Co.

4. Pan Am.

5. Sun Oil Co.

6. Shoreline Petr. Corp.

7. Humble Oil \& Rfg. Co.

8. Humble Oil \& Rfg. Co.

9. Phillips Petr. Co.
M. F. Garcia \#2

Hurria L \& L Co. \#A-10

Sauz-Ranch-Jardin \# 1

Coleman \# I

Scott \#1

Lorena Walker $\$ 1$

Williamar Unit \#1

Sauz-Ranch-Nopal \#2

Livingston \#1 


\section{RELIABLE CORRELATIONS FROM REGIONAL CROSS SECTIONS}

Regional cross sections, composed of electrical logs from closely spaced wells, along with adequate micropaleontological control, allow for reliable correlations within the Frio and the subdivision of this formation into several units.

In order to subdivide the Frio wedge into more manageable units, correlation points within the Frio must be established. This was accomplished on the basis of several assumptions: (1) the entire Frio thickens significantly downdip and, therefore, each genetic unit within the Frio also thickens; (2) major shale breaks represent longer periods of deposition than the intervening sand and will carry for greater distances with some reliability; (3) each genetic unit is transposed slightly seaward of the previous or older unit; and (4) each unit consists of a dominantly shale section with thin, discontinuous sands on the updip portion, thick extensive sands in the central portion, and dominantly shale on the downdip portion.

The pattern thus obtained consists of a series of sand-shale packages (figs, 12 and 13) which thicken toward the Gulf; sand percentages increase to approximately the present coast and then shale deposition becomes dominant. The updip limit of each package occurs nearer the Gulf than the preceding package (fig. 6b), a pattern which parallels very closely the updip limit of foraminife ral markers. 
A

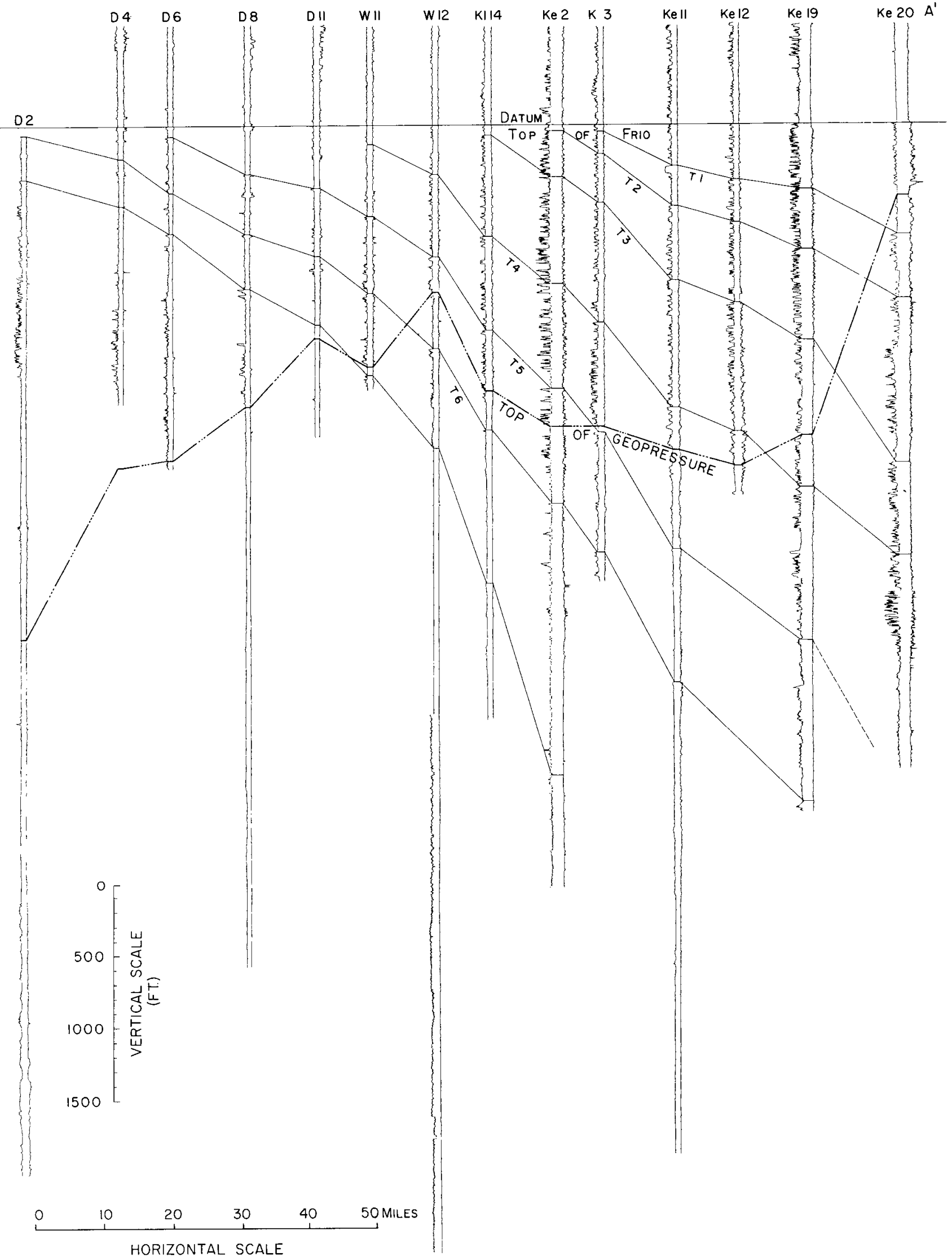

Fig. 12. Sand facies distribution along section $A-A^{\prime}$, datum on top of the Frio. " $T$ " markers indicate correlation points interpreted by using major shale beds and foraminifer zones. The top of the geopressured zone is indicated by the broken line. 
$\sigma$

。 


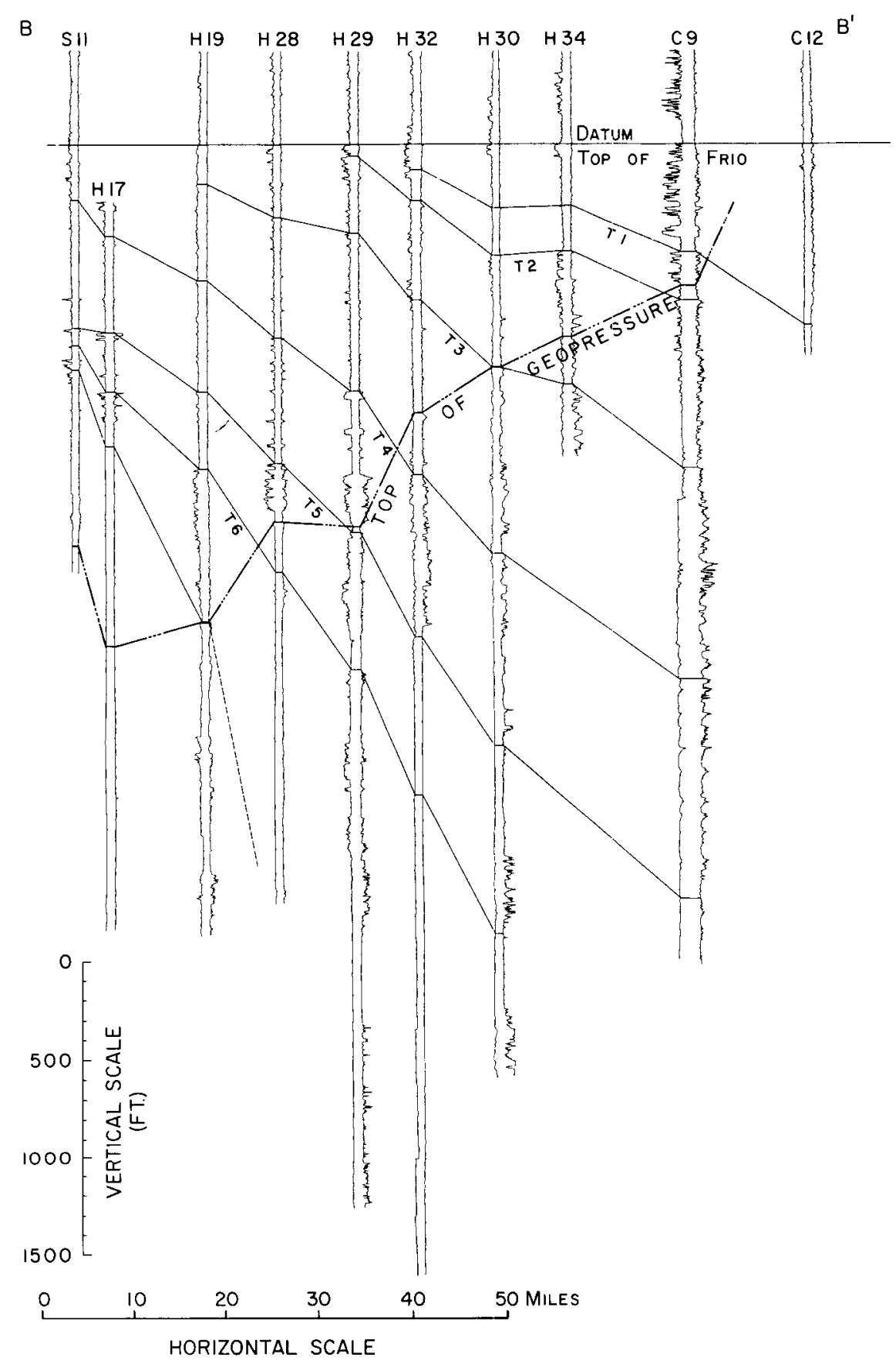

Fig. 13. Sand-facies distribution along section B-B', datum on top of the Frio. " $T$ " markers indicate correlation points interpreted by using major shale beds and foraminifer zones. The top of the geopressured zone is indicated by the broken line. 
Depositional systems, interpreted from sand-percentage maps, regional cross sections, and log patterns within each correlation unit, include fluvial plain, high-destructive wave-dominated delta, and strandplain.

Sand-percentage maps have been made of each unit (T0-T1, T1-T2, $\mathrm{T} 2-\mathrm{T} 3, \mathrm{~T} 3-\mathrm{T} 4, \mathrm{~T} 4-\mathrm{T} 5$, and $\mathrm{T} 5-\mathrm{T} 6)$; data for these maps were obtained from the interpretation of the spontaneous potential curve of electric logs on the cross section and from infill wells between sections. The total sand thickness for each unit was calculated for each well and then converted to percentage of the total thickness of the unit. These values, plotted on maps, have been contoured to depict sand distribution for each unit (figs. $14,15,17,18,19$, and 20$)$.

Depositional systems recorded by these sands and shales must be interpreted by using sand-percentage maps, in addition to cross sections and characteristic log patterns, thickness relationships of the associated sands and shales, and core data. Core control is sparse and contributed only to a very minor extent.

The depositional systems identified here include fluvial, highdestructive delta, and strandplain. The variations in the sand-shale ratio and distribution and geometry of the sand bodies which lead to the identification of the depositional systems is shown on a cross section of the T4-T5 zone (fig. 16).

Fluvial system--Sand is distributed in narrow, somewhat sinuous bands perpendicular to the coastline along the updip portion of the area. The sand bodies are commonly thin and are discontinuous laterally along strike. Individual sand bodies range in thickness from approximately 10 to 50 feet. The log patterns between and enclosing these fluvial channels indicate extensive areas very poor in sand. These areas, which are dominantly clay with very thin lignites, represent overbank and swamp or marsh environments.

High-destructive wave-dominated delta system--Along the Rio Grande in Hidalgo and Cameron Counties, thick sand bodies are oriented in a dip direction. The sand bodies are 100 to 600 feet thick and commonly are represented by a log pattern which indicates a gradational base and coarsening upward of the grain.size. The tendency for parts of the sand body to be strike oriented and the lack of significant lignites on an extensive delta plain suggest that the delta was highly destructive and wave dominated. Similar deltas of lesser lateral extent may also occur at the seaward end of the fluvial channels elsewhere along strike but are very minor in importance.

Few wells penetrate the Frio section seaward of the area of thick sand accumulation. Those that do show a dominantly shale section are interpreted as prodelta clay. The few sands in the prodelta environment are relatively thin (from 10 to 75 feet thick), become thinner gulfward, and are probably sheetlike in distribution.

Strandplain systems--Strandplain sands are by far the most dominant type of sand body in the South Texas Frio. These sand bodies are mapped as narrow bands parallel to strike and deposited by wave action and longshore currents into beach ridges and offshore bars. Complexes of these ridges and bars accumulate to form a broad belt 5 to 10 miles wide and 30 to hundreds of miles long. Individual sand bodies are from 10 to several hundred feet thick and are separated by shale units of a few feet to more than 100 feet thick. 


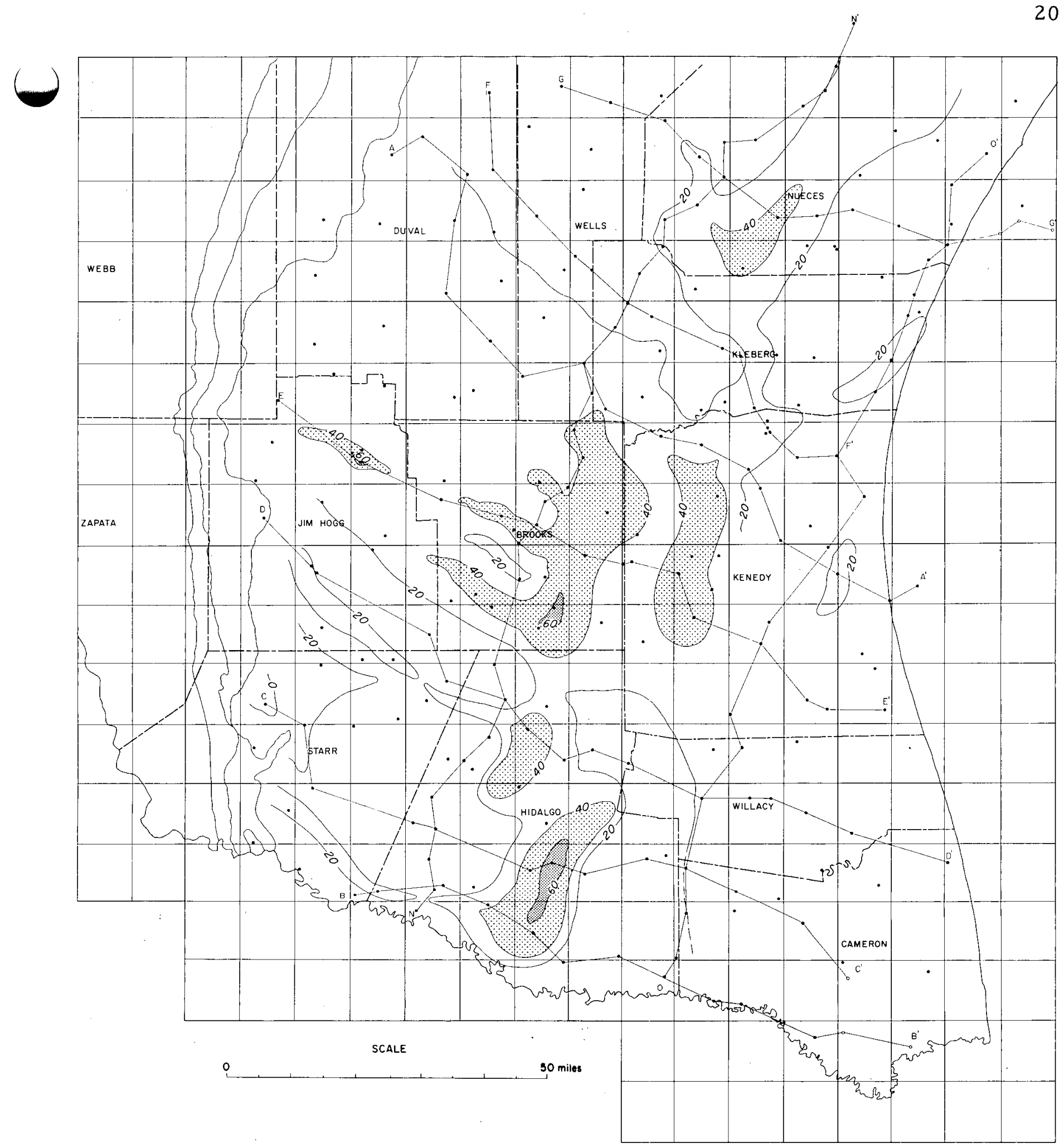

Fig. 14. Sand percentage in zone T5-T6. 


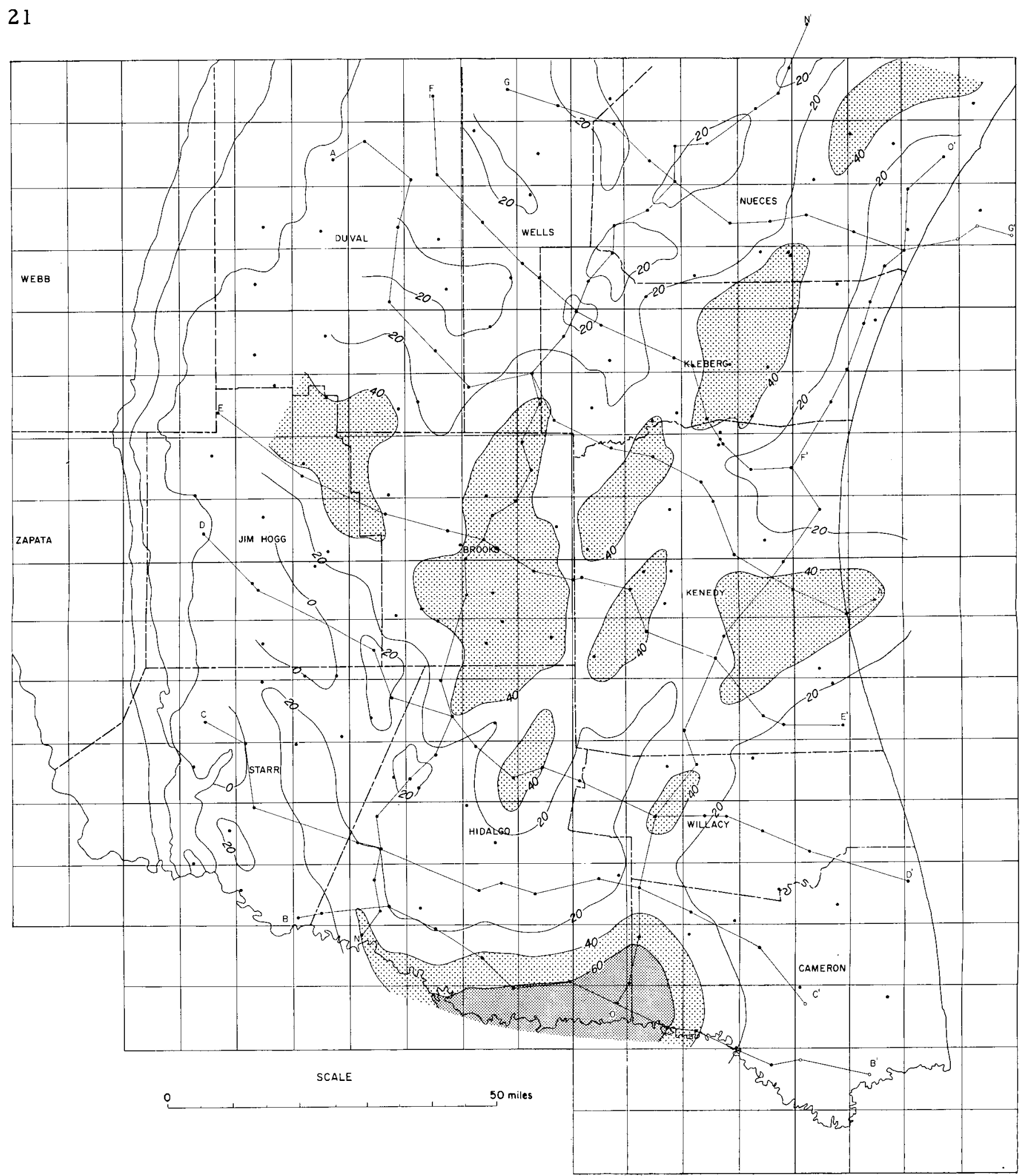

Fig. 15. Sand percentage in zone T4-T5. 


\section{FRIO SAND DISTRIBUTION}

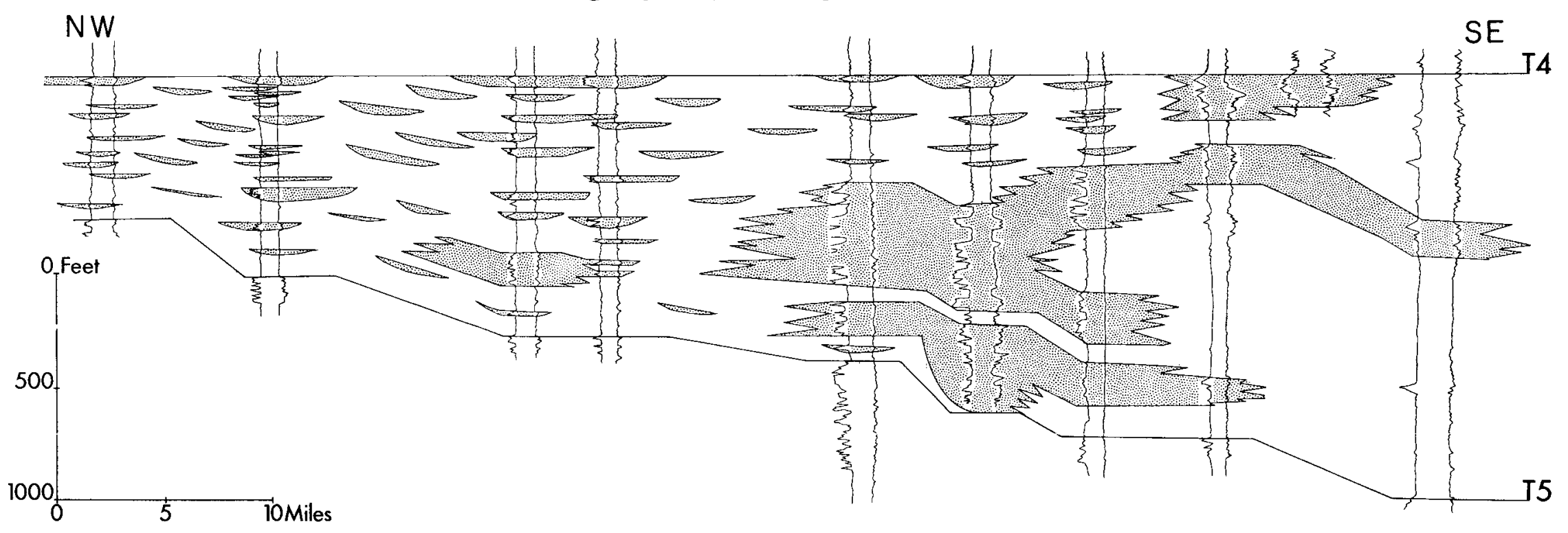

Fig. 16. Sand distribution between $\mathrm{T} 4$ and $\mathrm{T} 5$ along section $F-F^{\prime}$. 


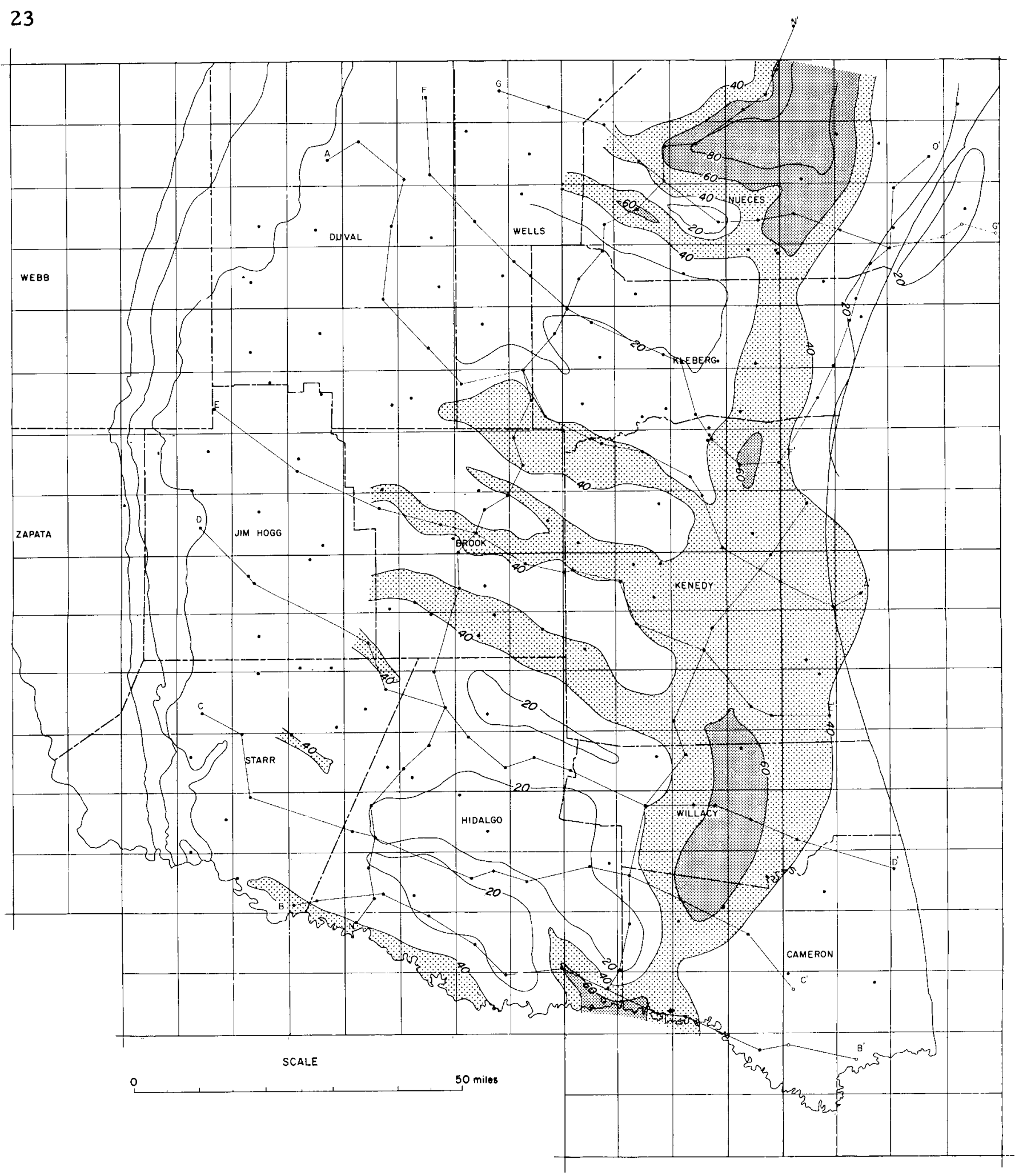

Fig. 17. Sand percentage in zone T3-T4. 


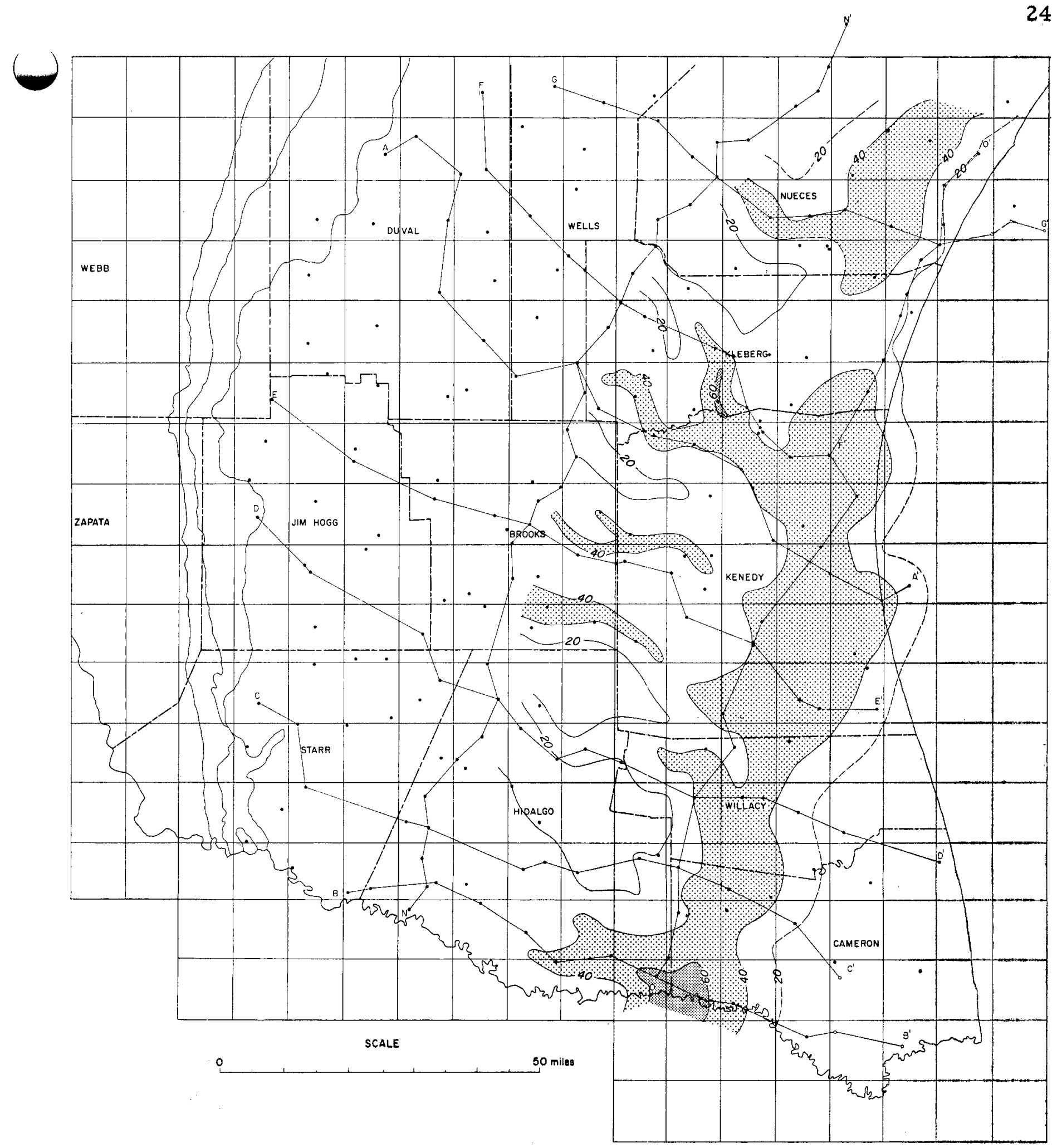

Fig. 18. Sand percentage in zone $\mathrm{T} 2-\mathrm{T} 3$. 


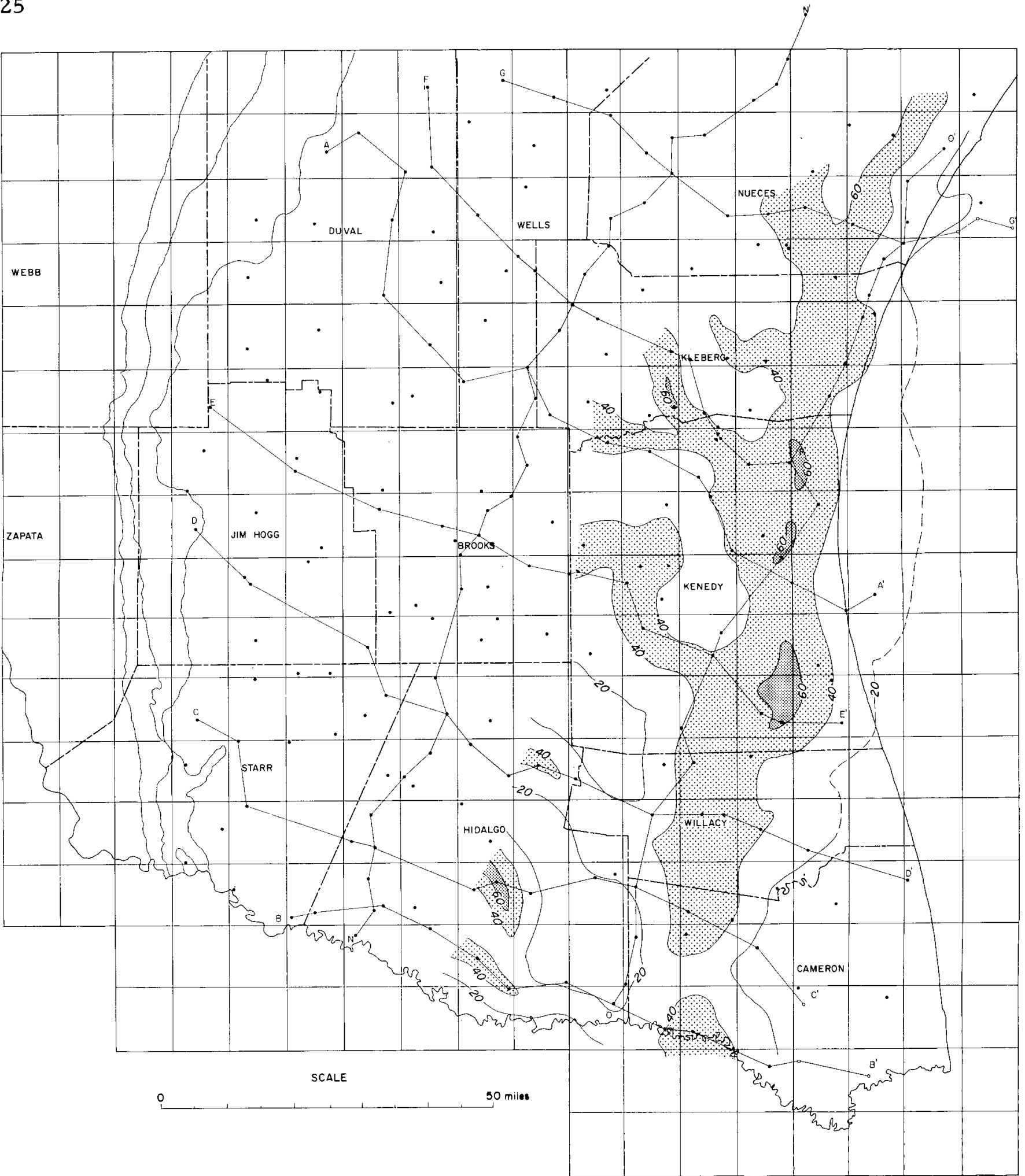

Fig. 19. Sand percentage in zone T1-T2. 


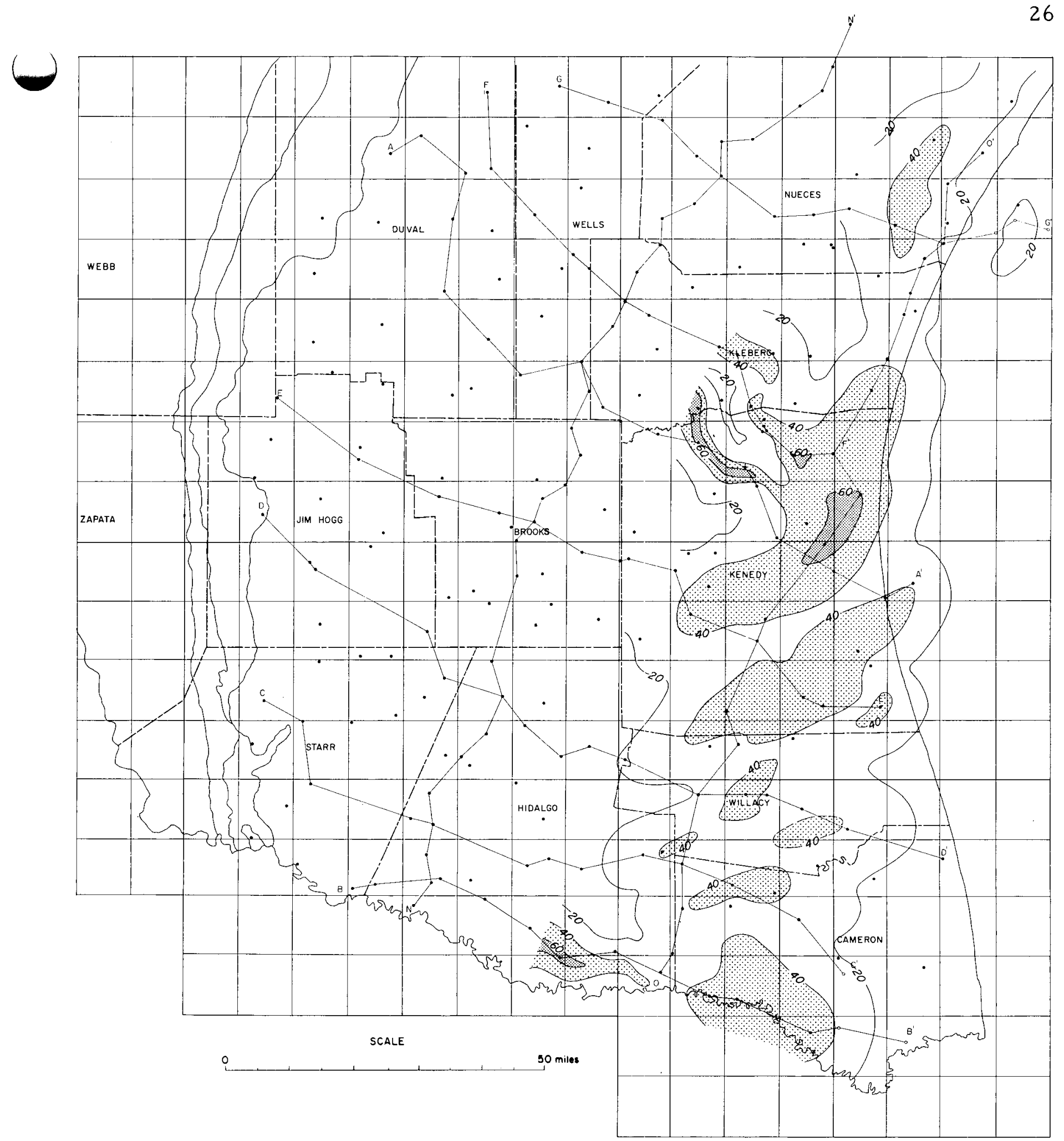

Fig. 20. Sand percentage in zone T0-T1. 


\section{GEOPRESSURED FRIO RELATED TO SAND DISTRIBUTION}

By mapping the top of the geopressured zone in the Frio, it can be shown that well-defined pressure patterns can be correlated with sand body geometry and distribution.

Geopressure is commonly defined as any zone in which the subsurface fluid pressure significantly exceeds that of normal hydrostatic pressure or approximately 0.464 psi for each foot of water column (Jones, 1969). An increase in the temperature and reduction of the salinity of the wate $r$ in the sand reservoirs in the geopressured zone accompany this increase in pressure. The occurrence of geopressure (considered in this report as 0.7 psi per foot) is identified primarily on the basis of welllogdata. The criteria used to identify this zone are (1) gradual reduction in the negative self-potential deflection, (2) increase in bottom-hole temperatures in excess of $225^{\circ} \mathrm{F}$, (3) increase in weight of drilling mudused to control geopressure, (4) location of the point of setting of intermediate casing which is usually at the top of the transition zone, and (5) reduction of density and resistivity of shale.

The presence of a broad band of geopressured sediments parallel to the Texas Coast has been well known for years (Jones, 1970). Where the geopressured zone crosses the Frio, it defines an irregular surface which varies in depth from 8,000 to 12,000 feet below sea level (fig. 21). The depth to the geopressured zone relates not only to the depth of the sediments below sea level but also to the amount of fluid leakage around growth faults which displaces the zone downward (fig. 8) and to the nature of the sandshale section. High-sand areas which are made up of relatively thin sand bodies separated by thin shales, typical of strandplain sediments, characteristically have depressed or deeper geopressured zones (fig. 12); on the other hand, high-sand areas which contain thick deltaic sand bodies separated by thick shales do not appea $r$ to affect the depth of geopressure (fig. 13). This relationship reflects the effectiveness of the thick shales separating the deltaic sands to seal the reservoir and the probability of considerable leakage through the thin shales of the strandplain sediments. 


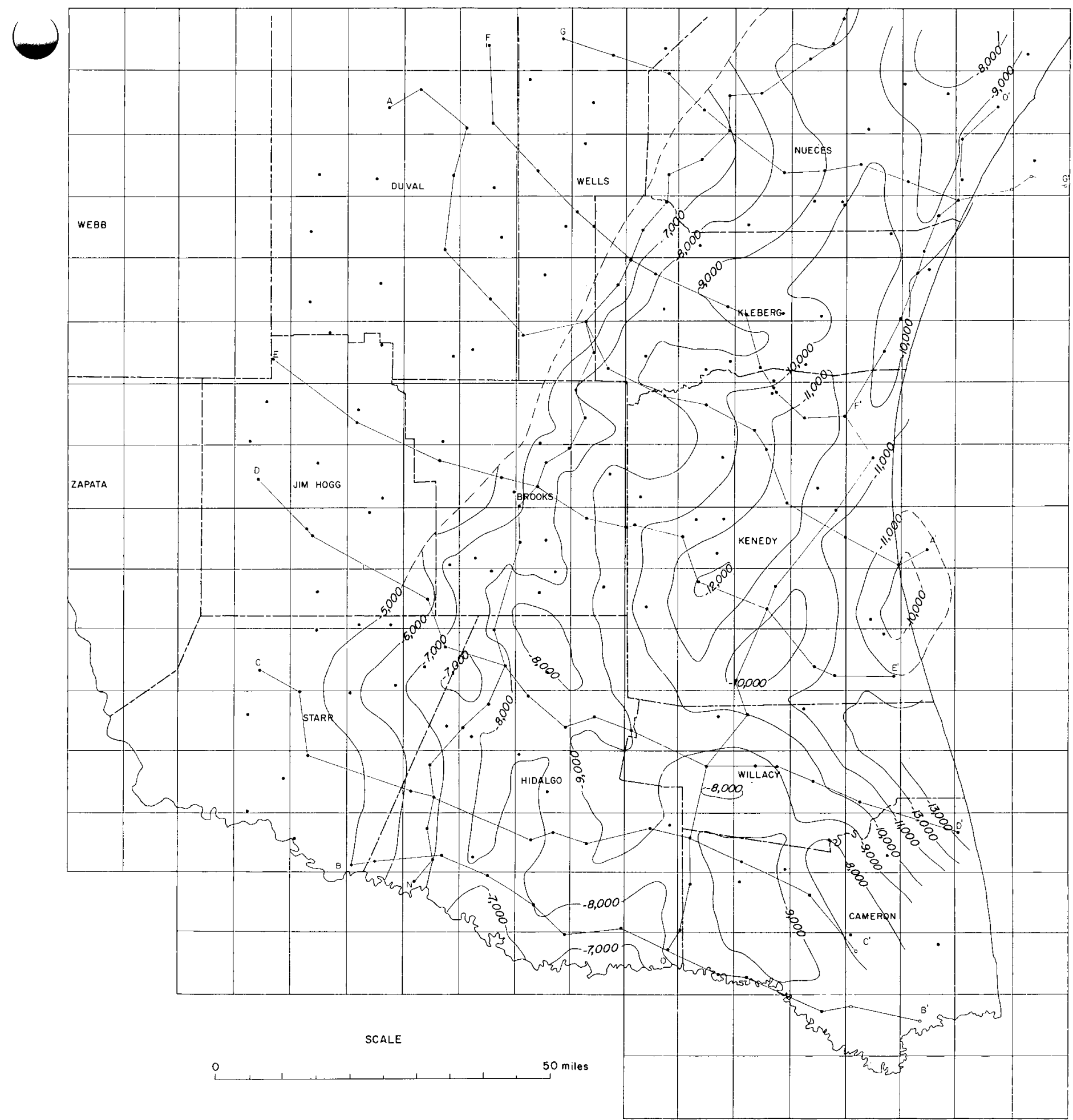

Fig. 21. Top of the geopressured zone, South Texas. 
ISOTHERMAL MAPS - T3, T4, and T5

Isothe rmal maps, constructed from well-log bottom-hole temperatures, show a steepening of the thermal gradients below $225^{\circ} \mathrm{F}$ and a relationship of high-sand areas with lower temperatures.

Isothermal maps have been constructed for correlation points $\mathrm{T} 3$, $\mathrm{T} 4$, and $\mathrm{T} 5$ (figs. 22, 23, and 24) based on uncorrected well-log bottomhole temperatures. Ramey (1962) has shown that stabilized temperature readings require extensive effort and commonly result in corrected temperatures only approximately $5^{\circ} \mathrm{F}$ higher than the routine readings. Because each of the wells used here has only one temperature reading in the Frio interval, the density of the data used for these maps is approximately one-third that used in the preparation of the other maps.
Two observations should be made on the basis of these very general isothermal maps, however. First, steepening of dipoccurs in each interval approximately at the $225^{\circ} \mathrm{F}$ isothe rmal line; this is consistent with Jones' (1970) observation that the top of geopressure occurs at temperatures between 210 and $240^{\circ} \mathrm{F}$ and that the rmal gradients may double below this zone. Second, lower temperatures seem to occur in areas of maximum sand deposition because the geopressured zone is displaced deeper in the se areas. 


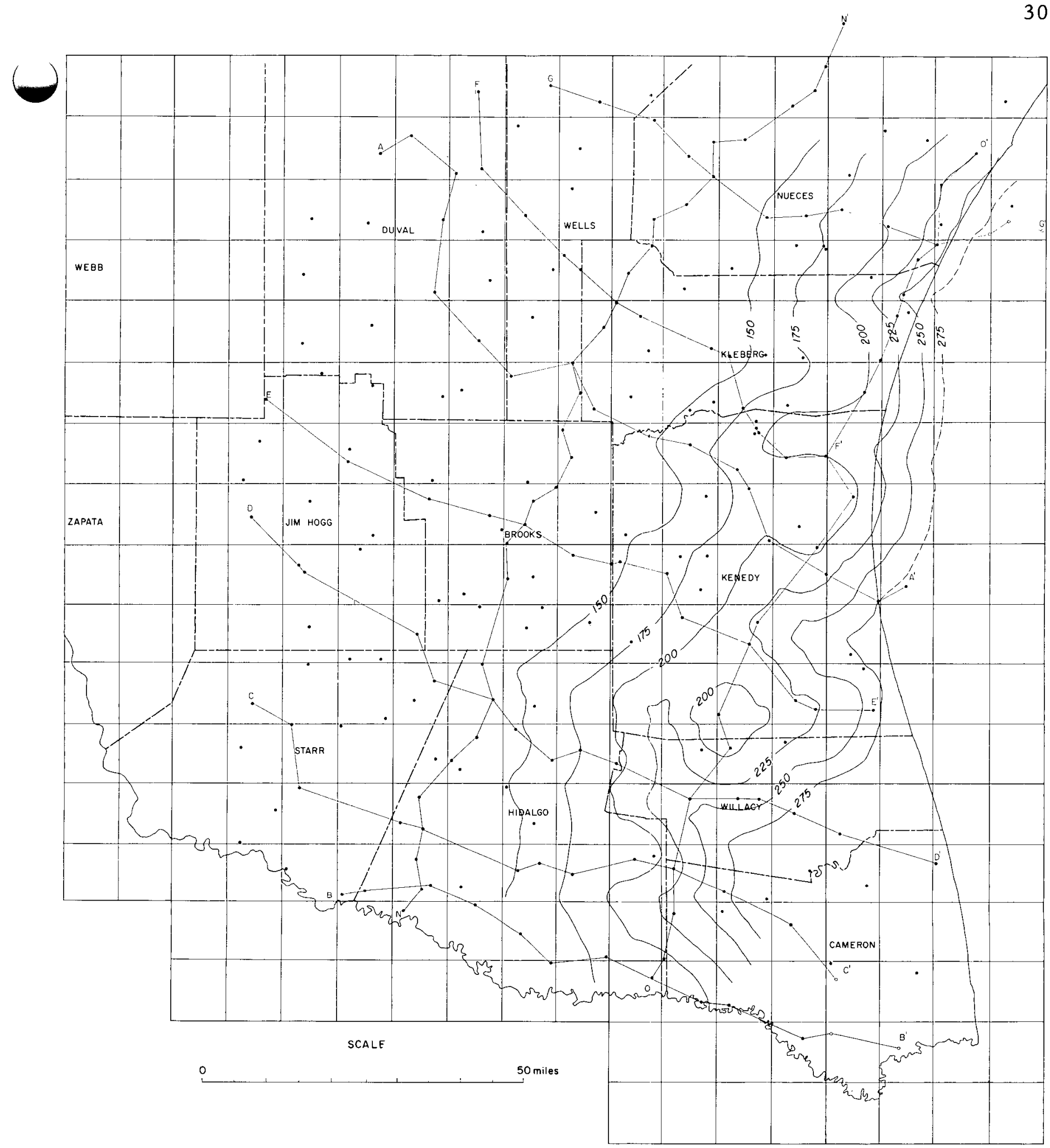

Fig. 22. Is othe rmal map on T3 datum. 
31

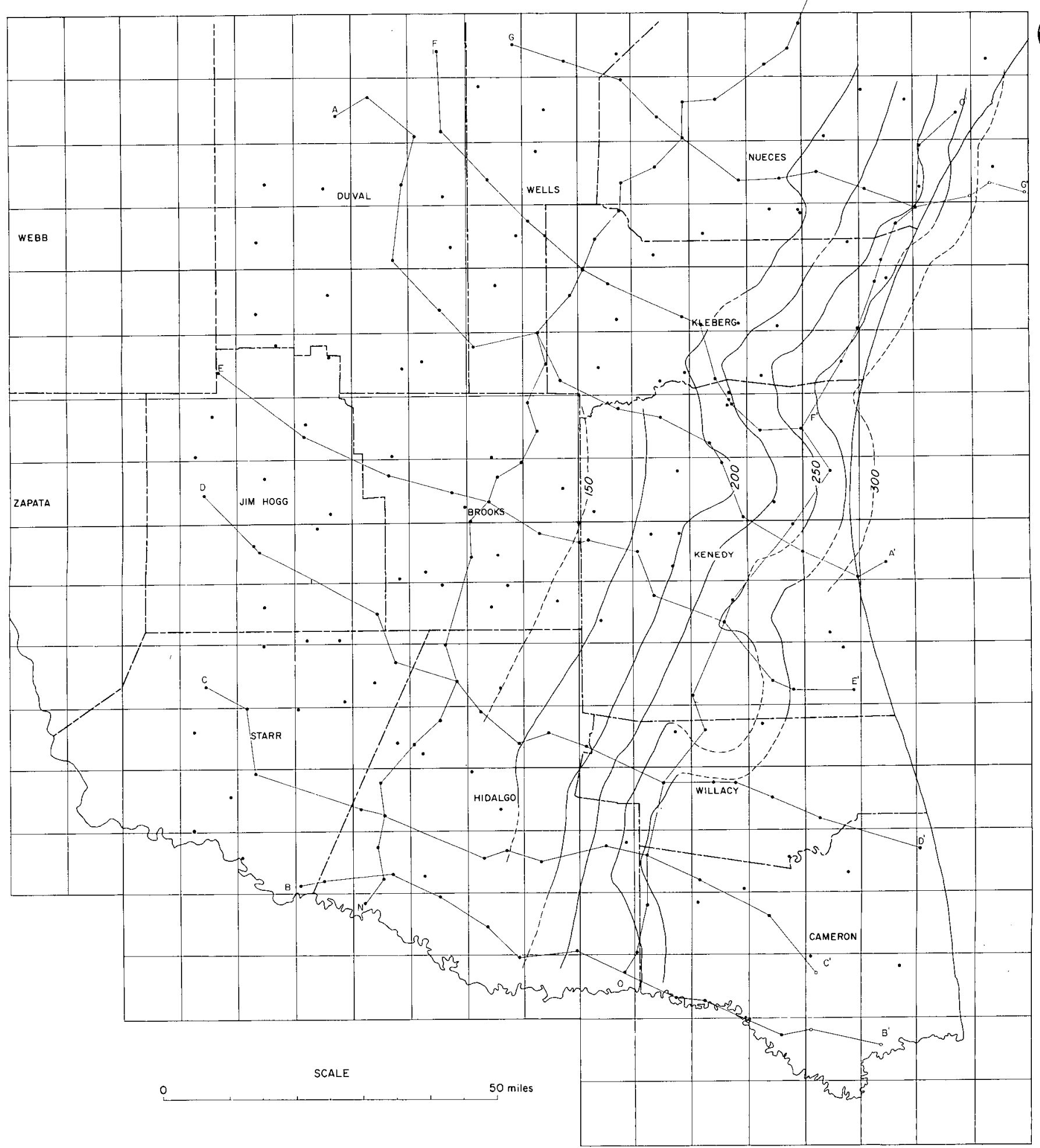

Fig. 23. Isothermal map on T4 datum. 


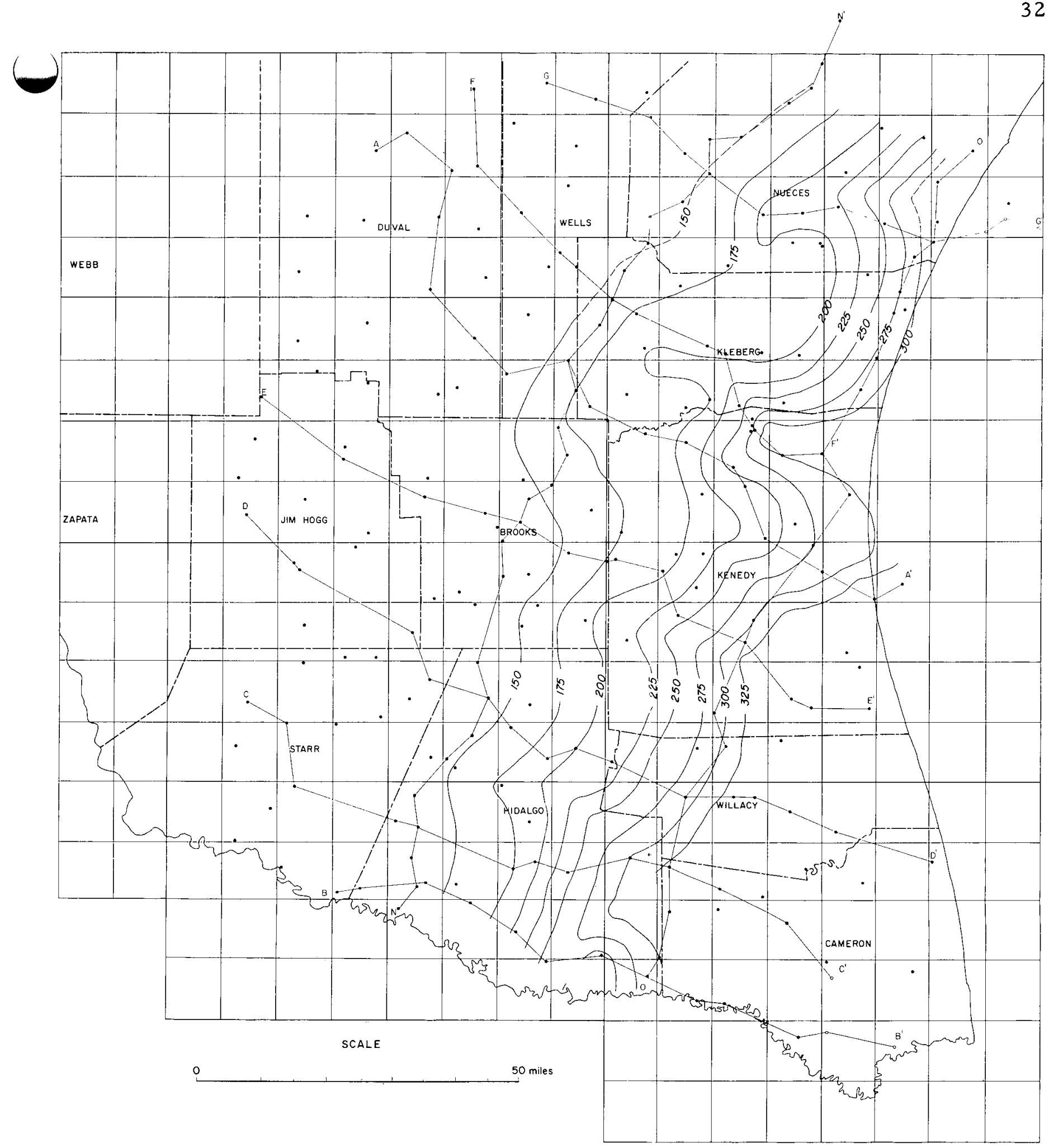

Fig. 24. Isothermal map on T5 datum. 
As a result of this preliminary study of sand distribution in the Frio, two potential geothermal fairways have been identified--one in the south part of the area in Hidalgo, Willacy, and Cameron Counties, and the other in the north part in north-central Nueces County.

Three major Frio sand depocenters have been delineated.

1. Southeastern Hidalgo, western Willacy, and western Cameron Counties. The highest sand ratios occur in the lower Frio in thick sand bodies (100 to 600 feet thick) which are primarily dip oriented. These sand bodies were deposited as highdestructive deltas.

2. Eastern Kenedy and Kleberg Counties. A high-sand a rea occurs in the upper Frio where sand bodies 10 to 100 feet thick are separated by thin shale intervals. These sand bodies are oriented in strike direction and accumulated mainly as strandplain deposits.

3. North-central Nueces County. In the middle Frio ( $\mathrm{T} 3-\mathrm{T} 4)$ a high ratio of sand occurs just at the northern part of the study area. Preliminary work farther north indicates that the se thicken conside rably in that direction.

Comparison of the sand-percentage maps with that of the top of the geopressure (fig. 21) further helps to delineate prospective geothermal fair ways. The sand reservoirs in the southern a rea (Hidalgo, Willacy, and Cameron Counties) and in the northern area (Nueces County) a re geopres sured at a shallow depth (7,000 to 9,000 feet) and are thus of considerable interest as a source of geothermal energy. In the central area (Kenedy and Kleberg Counties), on the other hand, the Frio sand percentage is as high as that of the area to the south but the sands are not geopressured. Thus, the central area is not as prospective for geothermal energy in the Frio section. The contrast in prospectiveness be- tween the southern and central areas relates directly to the depositional origin of the sand bodies. In the south ern area, the thick deltaic sands are separated by thick prodelta muds which effectively formed a seal for formation of geopressure (figs. 13 and 21). In the central area, thin strandplain sands are separated by very thin muds which apparently were noteffective seals; thus, geopressure is not maintained and the top of geopressure has been depressed to 10,000 to 12,000 feet (figs. 12 and 21).

The northern high-sand area is on the southe rn edge of a much thicker, more extensive sand complex developed north of the studyarea. A better understanding of the depositional system which deposited these sands will be obtained during the study of the regional sand distribution along the central Texas Gulf Coast.

Although the results of this study are preliminary, two potential geothermal fairways in the Frio of South Texas have been delineated--a southern area (Hidalgo, Willacy, and Cameron Counties) and a northern area (Nueces County). The next step necessary prior to selection of potential geothe rmal well sites is the initiation of local, detailed studies. Dense well control, core data, detailed wellhistory records, and short seismic sections will serve as the data base for the local studies. These studies should result in bette $r$ correlation of individual sand bodies, more precise definition of depositional systems, and, ultimately, better understanding of the nature of the reservoirs (fig. 25). 


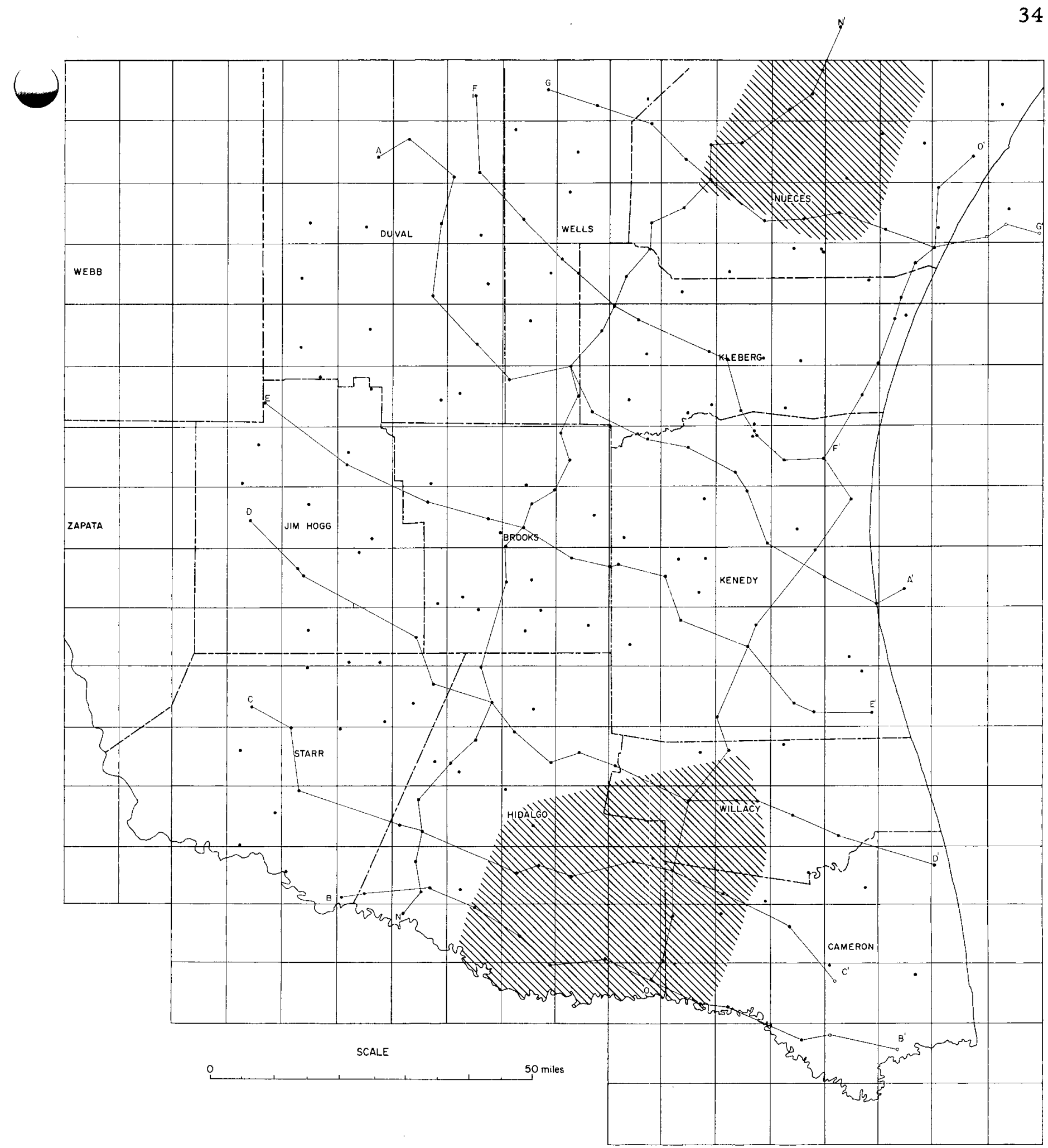

Fig. 25. Potential geothermal fairways. 
Sincere appreciation is expressed to Dr. Paul Jones, Water Resources Division, U. S. Geological Survey, for providing four regional correlation sections of the Tertiary of South Texas, which served as a guide for the construction of additional cross sections and for more detailed subdivision of the Frio interval.

Thanks are also extended to Exxon Company, USA, Mobil Oil Corporation, and Tenneco Oil for providing some basic data used in this report. 
Bruce, C. H., 1973, Pressured shale and related sediment deformation: mechanism for development of regional contemporaneous faults: Am. Assoc. Petroleum Geologists Bull., v. 57, p. 878-886.

Dorfman, Myron, and Kehle, R. O., 1974, Potential geothermal resources of Texas: Univ. Texas, Bur. Econ. Geology Geol. Circ. $74-4,33 \mathrm{p}$.

Fisher, W. L., and McGowen, J. H., 1967, Depositional systems in the Wilcox Group of Texas and their relationship to the occurrence of oil and gas: Gulf Coast Assoc. Geol. Socs., Trans., v. 17, p. 105-125. Reprinted as Univ. Texas, Bur. Econ. Geology Geol. Circ. 67-4. Proctor, C. V., Jr., Galloway, W. E., and Nagle, J. S., 1970, Depositional systems in the Jackson Group of Texas Their relationship to oil, gas, and uranium: Gulf Coast Assoc. Geol. Socs., Trans., v. 20, p. 234-261. Reprinted as Univ. Texas, Austin,
Bur. Econ. Geology Geol. Circ. $70-4$.

Guevara, E. H., and Garcia, R., 1972, Depositional systems and oil-gas reservoirs in the Queen City Formation (Eocene), Texas: Gulf Coast Assoc. Geol. Socs., Trans., v. 22, p. 1-22. Reprinted as Univ. Texas, Bur. Econ. Geology Geol. Circ. 72-4, p. 1-22.

Holcomb, W. C., 1964, Frio formation of southern Texas: Gulf Coast Assoc. Geol. Socs. Trans., v. 14, p. 23-33.

Jones, P. H., 1969, Hyd rodynamics of geopressure in the northern Gulf of Mexico basin: Jour. Petroleum Technology, v. 21, p. 803-810.

1970, Geothermal resources of the northern Gulf of Mexico basin: U. N. Symposium on the Development and Utilization of Geothermal Resources, Pisa 1970, v. 2, pt. 1, p. 14-26.

Ramey, H. J., 1962, Wellbore heat transmission: Jour. Petroleum Technology, v. 14, p. 427-435. 